\title{
20 Years of Global Change on the Limnology and Plankton of a Tropical, High-Altitude Lake
}

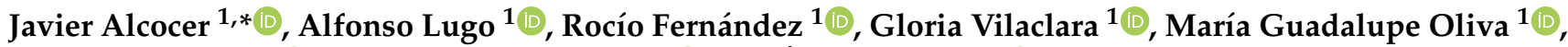 \\ Luis A. Oseguera ${ }^{1}{ }^{\mathbb{D}}$, Raúl A. Silva-Aguilera ${ }^{2}{ }^{\mathbb{D}}$ and Óscar Escolero ${ }^{3}{ }^{\mathbb{C}}$
}

1 Grupo de Investigación en Limnología Tropical, Facultad de Estudios Superiores Iztacala, Universidad Nacional Autónoma de México, Tlalnepantla 54090, Mexico; lugov@unam.mx (A.L.); biol.fernandez@gmail.com (R.F.); vilaclara.gloria@iztacala.unam.mx (G.V.); oliva.guad@gmail.com (M.G.O.); loseguera@unam.mx (L.A.O.)

2 Programa de Posgrado en Ciencias del Mar y Limnología, Universidad Nacional Autónoma de México, Mexico City 04510, Mexico; raul.s@ciencias.unam.mx

3 Dinámica Terrestre Superficial, Instituto de Geología, Universidad Nacional Autónoma de México, Mexico City 04510, Mexico; escolero@geologia.unam.mx

* Correspondence: jalcocer@unam.mx

check for updates

Citation: Alcocer, J.; Lugo, A.; Fernández, R.; Vilaclara, G.; Oliva, M.G.; Oseguera, L.A.; Silva-Aguilera, R.A.; Escolero, Ó. 20 Years of Global Change on the Limnology and Plankton of a Tropical, High-Altitude Lake. Diversity 2022, 14, 190.

https://doi.org/10.3390/d14030190

Academic Editors: Paolo Pastorino, Marino Prearo and Michael Wink

Received: 1 February 2022

Accepted: 2 March 2022

Published: 5 March 2022

Publisher's Note: MDPI stays neutral with regard to jurisdictional claims in published maps and institutional affiliations.

Copyright: (c) 2022 by the authors. Licensee MDPI, Basel, Switzerland. This article is an open access article distributed under the terms and conditions of the Creative Commons Attribution (CC BY) license (https:// creativecommons.org/licenses/by/ $4.0 /)$.

\begin{abstract}
The present long-term (1993-2013) study was aimed at identifying the effects of global change on the environmental characteristics and the plankton community of the tropical, highaltitude Lake Alchichica, Puebla, Mexico. We found no statistically significant increasing trend in air temperature, but an increase from 2002 to 2013, and interannual variability in the meteorological variables. Accordingly, the water temperature rose from 1993 to 2003 and remained similar until 2013. Nonetheless, on a longer-term (1966-2018), longer than the period considered in the present study, air and water temperatures showed an increasing trend in the range considered indicative of climate change. The lake displayed a characteristic warm monomictic thermal pattern but exhibited interannual variability. The planktonic community composition and structure remained similar. The small chlorophytes (e.g., Monoraphidium minutum) dominated the phytoplankton abundance, while the large diatom Cyclotella alchichicana dominated the biomass. The calanoid copepod Leptodiaptomus garciai dominated both the zooplankton abundance and biomass. However, as the temperature increased the large-size phytoplankton (i.e., C. alchichicana) abundance and biomass increased, but the small-size phytoplankton abundance and biomass, as well as the adult copepod abundance and biomass, decreased. The increase in temperature could have favoured the large-size over the small-size phytoplankton. In addition, the temperature increase could have negatively affected the calanoid copepods in two different ways-direct association with the negative effects of higher temperatures on the physiology of the copepods, or indirect association with the negative effects of higher temperatures on the small-size phytoplankton, which diminish the copepods' food resource.
\end{abstract}

Keywords: climate change; eutrophication; phytoplankton; zooplankton; Lake Alchichica; Mexico

\section{Introduction}

The Anthropocene identifies the most recent geological time in Earth's history, when anthropogenic activities have significantly impacted the planet, leading to global planetaryscale environmental changes. The beginning of this time is most appointed to 1610 or 1964 [1]. Global change then refers to the environmental changes related to human activities through the Anthropocene that impact the key processes controlling the functioning of the ecosystems [2]. Various stressors, such as climate change and eutrophication, threaten freshwater ecosystems, adversely affecting their biodiversity and ecosystem services [3]. Besides the recent human-induced climate change, natural climate variability persists, which follows quasi-cycling atmospheric circulation patterns [4] 
Lakes have long been recognized as sentinels of environmental change [5,6] and most climate change and climate variability indicators [7-9]. Unfortunately, the effects of global change on tropical lakes have been far less studied (e.g., $[10,11])$ than in temperate freshwater ecosystems. Moreover, most of these studies approach the issue through paleolimnology (e.g., $[12,13])$ and not long-term monitoring (e.g., $[14,15])$. Mexican lakes are no exception. The studies exhibiting the intense anthropic disturbances in Mexican lakes from the 1950s and 1960s onwards are mostly paleolimnology-based (e.g., [16-19]), and only a few are based on long-term monitoring (e.g., [20]).

In this study, our primary goal was to identify if and how the environmental characteristics and the plankton community of a tropical, high-altitude lake have been modified by global change. For this purpose, we addressed the following research questions: (1) How has climate (i.e., temperature, precipitation, evaporation) changed during the studied 20 years? (2) How have the main limnological characteristics changed during the studied 20 years? (3) How have the phytoplankton and zooplankton communities' composition and structure changed during the studied 20 years?

Our central hypothesis was that global change has affected the environmental and biological communities in the lake. Specifically, we expected these changes to cause (1) warmer temperatures through global warming, (2) lake eutrophication associated with land-use intensification (e.g., agriculture), and (3) phytoplankton and zooplankton composition and structure modifications according to global warming and eutrophication.

To answer the research questions and test the proposed hypothesis, our approach was to evaluate (a) the temporal changes in the air temperature, rainfall, and evaporation using meteorological data derived from monthly monitoring within the studied 20 years (1993 to 2013), and (b), the temporal changes in the water quality and the plankton community using data derived from monthly monitoring of the water column physical and chemical variables, chlorophyll $a$ concentration as a proxy of the lake's primary productivity, and the phytoplankton and zooplankton communities' compositions and structures of the lake within the studied 20 years (1993, 2003, and 2013).

\section{Materials and Methods}

\subsection{Study Area}

Lake Alchichica is a crater (maar) lake at $19^{\circ} 24^{\prime} \mathrm{N}$ and $97^{\circ} 24^{\prime} \mathrm{W}$ in the endorheic Cuenca Oriental (Figure 1). It is a high-altitude lake located at $2326 \mathrm{~m}$ a.s.l. The air temperature average is $14.4^{\circ} \mathrm{C}$ [21]. The annual precipitation is less than $500 \mathrm{~mm}$, while the annual evaporation is $1690 \mathrm{~mm}$ [22]. Groundwater is the main water source of the lake [23].

The Lake Alchichica surface area is $2.3 \mathrm{~km}^{2}$, the water volume is $114,688,900 \mathrm{~m}^{3}$, the

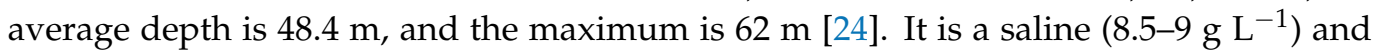
alkaline ( $\mathrm{pH} \sim 9$ ) lake with a chemical composition where sodium, magnesium, chlorides, and bicarbonates dominate $[23,25]$.

Alchichica is a tropical, warm monomictic lake, with a circulation period between late December or early January and March, and stratifying the rest of the year [26]. The lake is oligotrophic, with low nutrient and chlorophyll $a$ concentrations in the mixed layer [27].

\subsection{Field Sampling}

Daily records of average air temperature, rainfall, and evaporation for the 1993 to 2013 period were obtained from the Servicio Meteorológico Nacional weather station SMN-21052, at the lake's southwest coastal area $\left(19^{\circ} 24^{\prime} 43^{\prime \prime} \mathrm{N}, 97^{\circ} 23^{\prime} 38^{\prime \prime} \mathrm{W}, 2343 \mathrm{~m}\right.$ a.s.l.). The missing air temperature and evaporation values in the original database were calculated using the double masses method with the nearest weather station SMN-30198. The method assumes that a pair of datasets are proportional if the resulting curve of plotting one's cumulative values against the other's is a straight line; the line's slope represents the proportionality constant between data [28]. The calculated proportionality constant obtained the estimation of the missing values from SMN-21052 in terms of SMN-3040 $\left(19^{\circ} 24^{\prime} 50^{\prime \prime} \mathrm{N}, 97^{\circ} 23^{\prime} 20^{\prime \prime} \mathrm{W}\right.$, $2350 \mathrm{~m}$ a.s.l.) data. The rainfall missing data were calculated using the rainfall daily dataset 
of twelve neighbouring SMN weather stations (Silva-Aguilera et al. in prep.). All variable daily datasets were sampled monthly, obtaining the mean air temperature value and the sums of rainfall and evaporation.
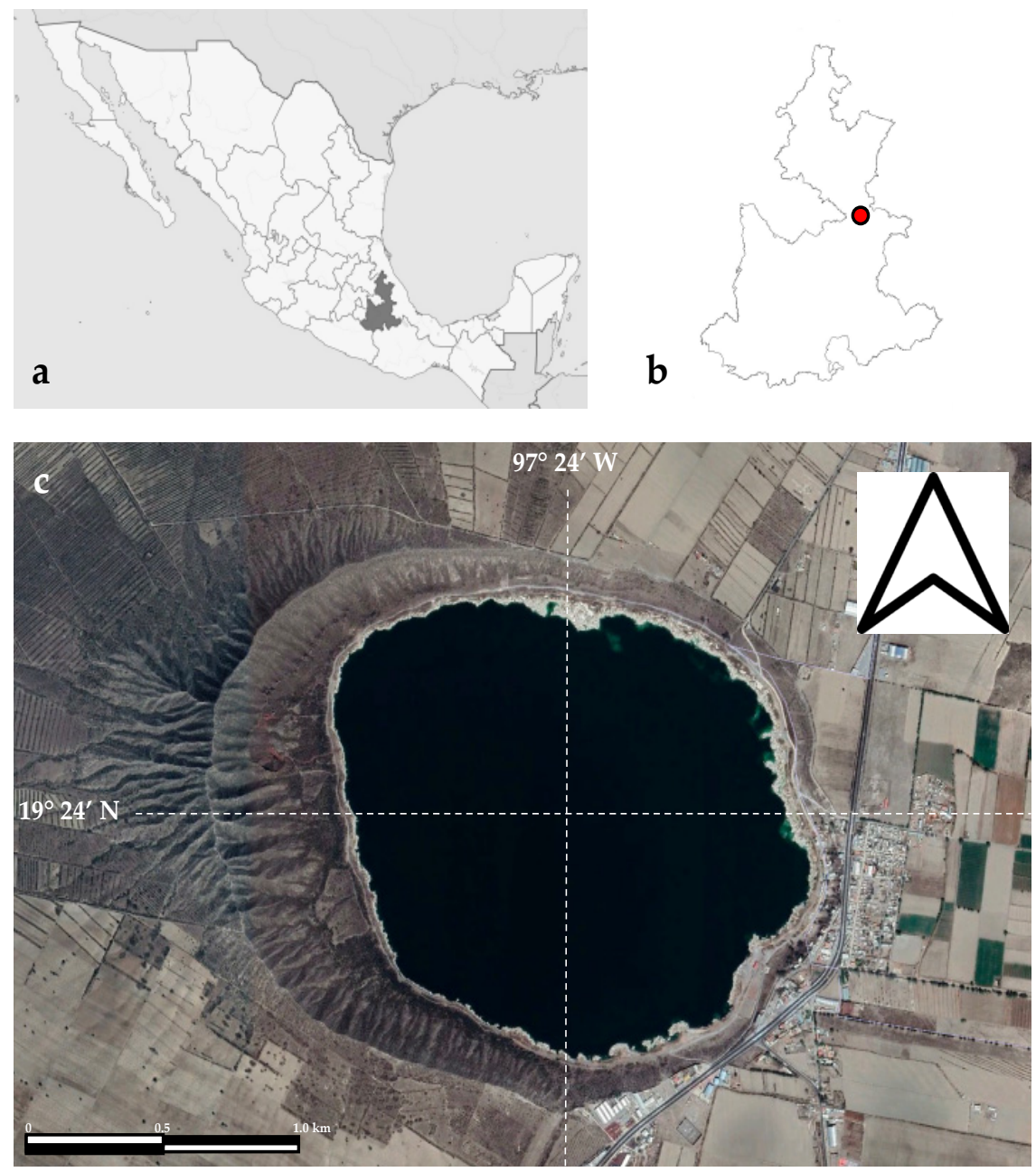

Figure 1. Location of Lake Alchichica in (a) Mexico and (b) Puebla State. (c) Lake Alchichica (satellite photograph from Google Earth).

Three one-year sampling campaigns were carried out over 20 years (1993-1994, 2003, and 2013). Lake Alchichica hydrodynamics were evaluated by recording the monthly temperature and dissolved oxygen profiles at the central and deepest part of the water body. Both variables were measured (1 m vertical resolution) with a Hydrolab (DS4 in 1993-1994 and 2003, and DS5 in 2013) multiparametric water quality probe. The photosynthetically active radiation (PAR) was measured with a Biospherical PNF-300 natural fluorescence profiler (25-30 cm vertical resolution). The euphotic zone $\left(Z_{\mathrm{EU}}\right)$ extended from the surface down to where the PAR was $\geq 0.1 \%$ of its surface value (SPAR). The mixed layer ( $\left.Z_{\text {MIX }}\right)$ comprises the water surface down to the top of the thermocline when stratified, while it corresponds to the entire water column during the mixing season.

At each sampling date, three sets of ten water samples (water sampler bottle: 5-L Van Dorn in 1993-1994 and 2003, and 5-L Uwitec in 2013) were collected along the water column. The ten water depths at each sampling campaign were chosen to better represent the water column heterogeneity (e.g., euphotic zone, thermo-, and oxyclines) after recording the PAR, temperature, and dissolved oxygen profiles. The first set was for analysing the chlorophyll $a$ concentration (Chl-a), the second set was for phytoplankton, and the third set was for zooplankton. The Chl-a values were analysed according to the EPA method 445.0 (Turner 
Design TD-10 fluorometer, [29]) and in two size fractions-large (LChl- $a \geq 2 \mu \mathrm{m})$ and small (SChl- $a<2 \mu \mathrm{m}, \geq 0.7 \mu \mathrm{m}$ ).

The samples for the phytoplankton counts were preserved with acid Lugol's solution ( $1 \%$ final concentration). The phytoplankton counts were done using $50-\mathrm{mL}$ settling chambers with an Invertoscope D of Carl Zeiss by the Utermöhl [30] method, which facilitates the identification and counting of phytoplankton sizes for nanoplankton $(2-20 \mu \mathrm{m})$ and microplankton $(>20 \mu \mathrm{m})$. The abundance of the seven species (cells $\left.\mathrm{mL}^{-1}\right)$ was converted into the biovolume ( $\mu \mathrm{m} \mathrm{mL}^{-1}$, based on [31]) as a proxy for the biomass, the term used in the text. The identification was carried out following keys and specialized literature (e.g., [32-40]).

The zooplankton samples were filtered through $55 \mu \mathrm{m}$ mesh, concentrated in vials, and preserved with formalin (4\%) with added Bengal rose [41]. Copepod counts considered every developmental stage (nauplii, copepodites, males, females, and ovigerous females). When possible, at least $40-50$ individuals were counted in each sample to obtain a coefficient of variation between 30 and $50 \%$ [42].

The identification of the three zooplankton species was carried out following Koste [43] for Hexarthra sp., Mills et al. ([44]) for Brachionus sp., and Montiel-Martínez et al. [45] for Leptodiaptomus garciai. The copepod biomass as dry weight $(\mathrm{W})$ was calculated using the total length measure ( $\mathrm{L}$ in $\mathrm{mm}$, excluding the caudal setae) with the formula $\mathrm{W}=7.6637 \mathrm{~L}^{1.8911}$ for larvae, and $\mathrm{W}=6.6705 \mathrm{~L}^{2.0374}$ for copepodites and adults [46]. The rotifer biomass was evaluated as a biovolume calculated based on the geometric formulas proposed by RuttnerKolisko [47]. The wet weight was estimated from the biovolume of each individual using a specific density of 1.0, and the dry weight corresponded to $10 \%$ of the wet weight [48]. The copepod and rotifer abundance and biomass values were water-column integrated on an aerial basis (i.e., $\mathrm{m}^{2}$ ) and expressed as individuals $\mathrm{m}^{-2}$ for abundance and $\mathrm{mg} \mathrm{DW} \mathrm{m} \mathrm{m}^{-2}$ for biomass.

\subsection{Statistical Analysis}

We performed time series decomposition to the monthly records of weather variables to express the observed data in terms of their long-term trend, annual (i.e., seasonal), and random components using the R's decompose function from the stats library [49].

Linear correlations among meteorological variables throughout the study period and global climate indices were estimated using the Spearman coefficient. The used climate indices were the Oceanic Niño Index (ONI), the Southern Oscillation Index (SOI), the Pacific Decadal Oscillation index (PDO), and the Atlantic Multidecadal Oscillation index (AMO), downloaded from the NOAA's website [50].

Linear trends were estimated using the slopes of simple linear regressions applied to daily and monthly air temperature, evaporation and rainfall values. In the case of rainfall, the same was estimated for the dry and rainy season values. Data analysis and processing were made using R software.

Differences between environmental and biological data of the three studied years were established using the Mann-Kendall test. The Kruskal-Wallis test was used to find significant differences in the variables among the years by using the statistical software PAST 4.06 [51]. Finally, Spearman correlation coefficients were calculated to relate the environmental variables to the planktonic species abundances and biomass data, and between the phytoplankton and zooplankton abundance and biomass. The probability values were adjusted using the Bonferroni correction in PAST 4.06 [51].

\section{Results}

\subsection{Climate}

The 1993-2013 average air temperature increased from its lowest value in January to its highest in May and June. Then, the temperature decreased slightly in July and increased in August to reach similar previous values. From August on, the temperature decreased to the lowest value in January (Figure 2). Rainfall reached the highest value in June, and 
then it decreased (62\%) in July, probably reflecting the effect of the "canicular". Rainfall increased again from August and reached the second-highest value in September. From September, rainfall decreased until a complete absence of rainfall in January.

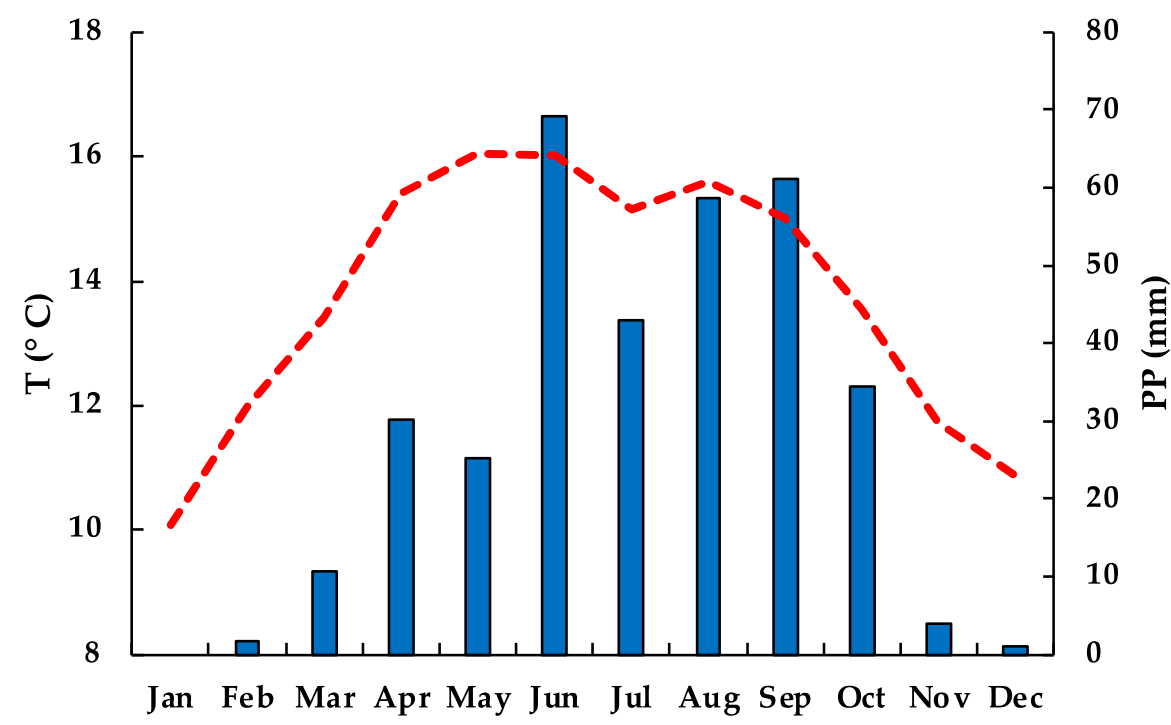

Figure 2. Station SMN-21052 climograph of normal monthly values for the 1993-2013 period. Average mean air temperature - $\mathrm{T}$ (red dotted curve); total rainfall—PP (blue bars).

These results allow for differentiating a warm (April to September) and a cold (October to March) period, and a rainy (June to October) and a dry (November to May) period. Therefore, there is a warm and rainy season (June to September), a cold and dry season (November to March), and two transitional periods between them-a cold and rainy (October), and a warm and dry (April to May). There were no statistically significant trends for the period of increasing or decreasing annual air temperature.

Th air temperature varied between colder and warmer conditions from 1993 to 2002 (Figure 3). From 2002 on, the air temperature increased until 2013, the end of the record. The monthly air temperature correlated with all the tested indices-positively with ONI $(r=0.13, p<0.05)$, negatively with SOI $(r=-0.17, p<0.05)$, positively with PDO $(r=0.14$, $p<0.05)$, and positively with AMO $(r=0.31, p<0.05)$.

There were no statistically significant trends of increasing or decreasing annual rainfall, nor when analysed separately in the dry and rainy seasons. Rainfall monthly values decreased from 1993 to 1999 (Figure 4). From 1999 on, there were fluctuations between rainier and drier periods until 2013, the end of the record. The monthly rainfall had a negative linear correlation with the SOI $(r=-0.16, p<0.05)$ and a positive linear correlation with the AMO index $(r=0.24, p<0.05)$.

There was a statistically significant decreasing trend in the monthly evaporation values from 1993 to $2013(-0.14, p<0.05)$. Higher evaporation values occurred in 1996 and from then on, evaporation decreased gradually until 2000 (Figure 5). Evaporation increased in 2001 and 2002, and from 2002 on, it decreased and sustained similar low values until 2013. There were statistically significant negative trends for the evaporation values of November $(r=-1.73, p<0.05)$, December $(r=-1.39, p<0.05)$, and January $(r=-1.92, p<0.05)$. The monthly evaporation values correlated positively with the PDO index $(r=0.30, p<0.05)$. 


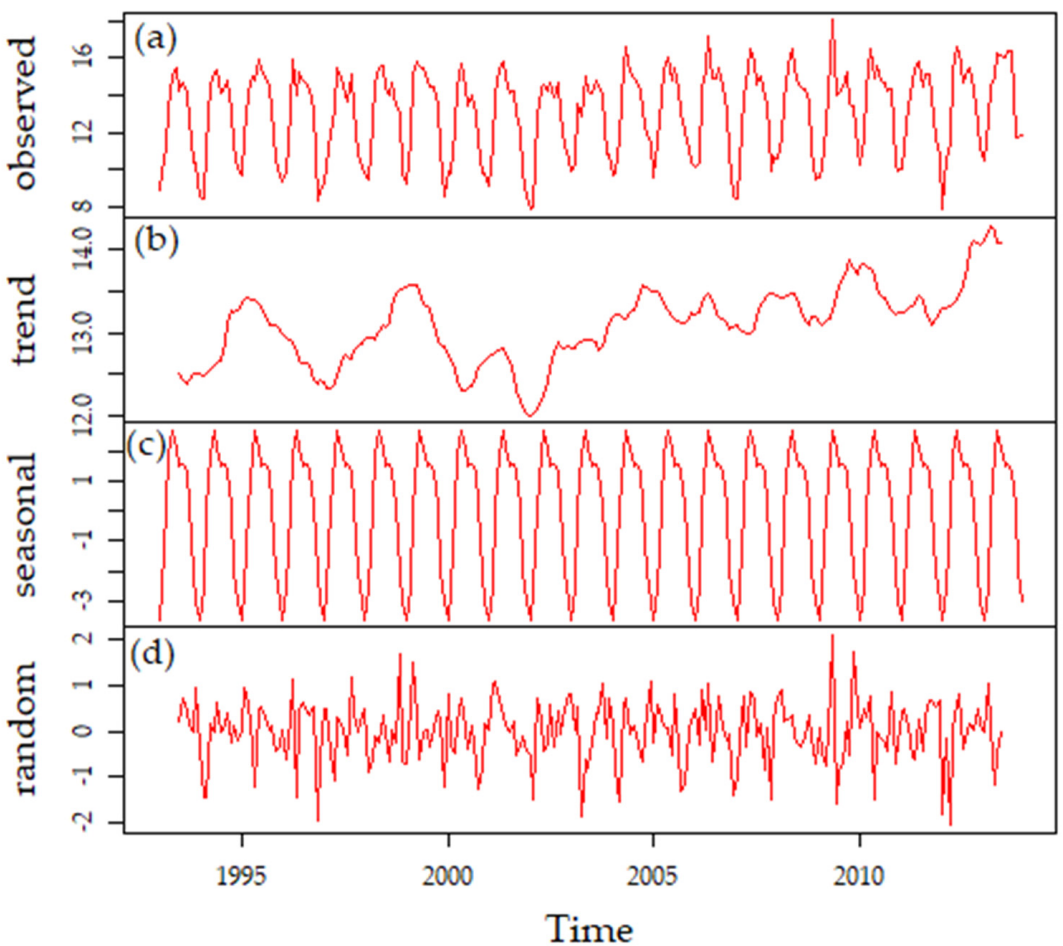

Figure 3. Decomposition of additive time series of monthly air temperature values recorded at the SMN weather station 21,052 (1993 to 2013). The observed data is represented in the upper panel (a), while the next panels show the additive components [(b) long-term trend, (c) seasonal, and (d) random components].

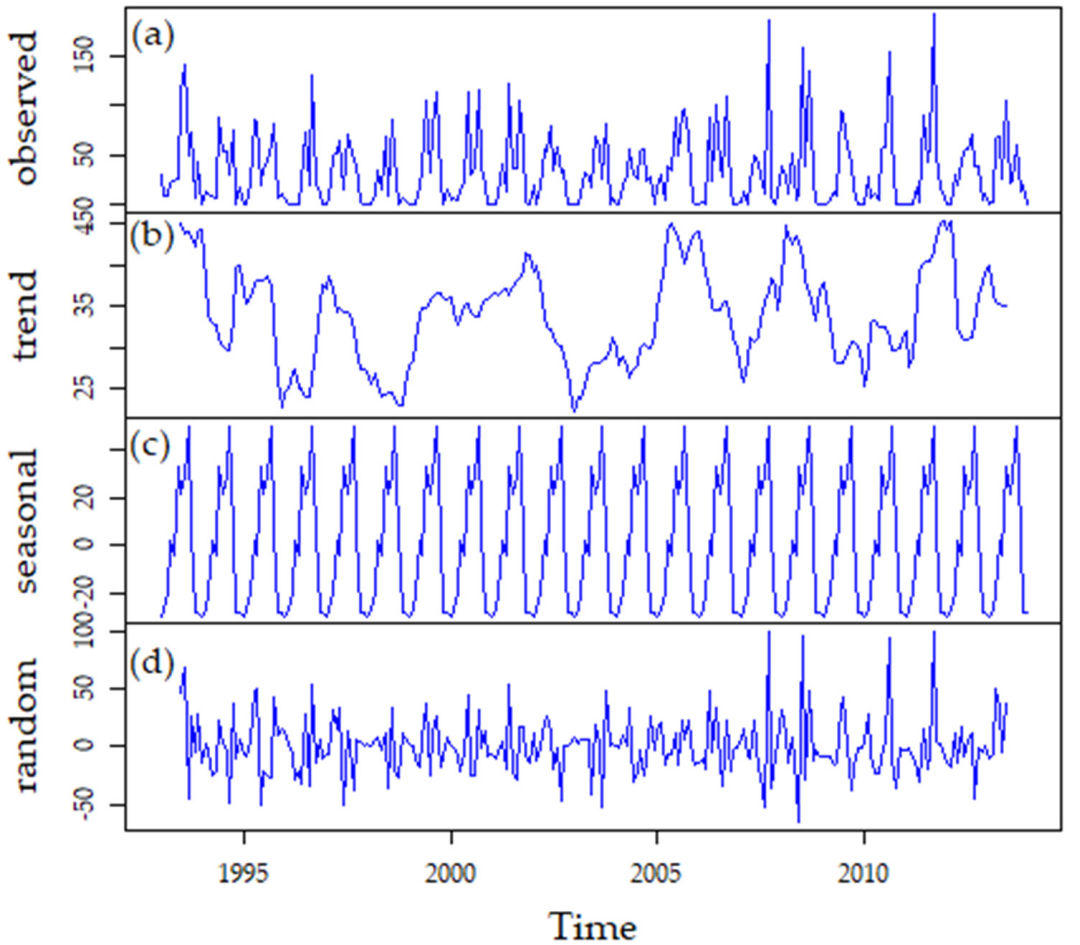

Figure 4. Decomposition of additive time series of monthly rainfall values recorded at the SMN weather station 21,052 (1993 to 2013). The observed data is represented in the upper panel (a), while the next panels show the additive components [(b) long-term trend, (c) seasonal, and (d) random components]. 


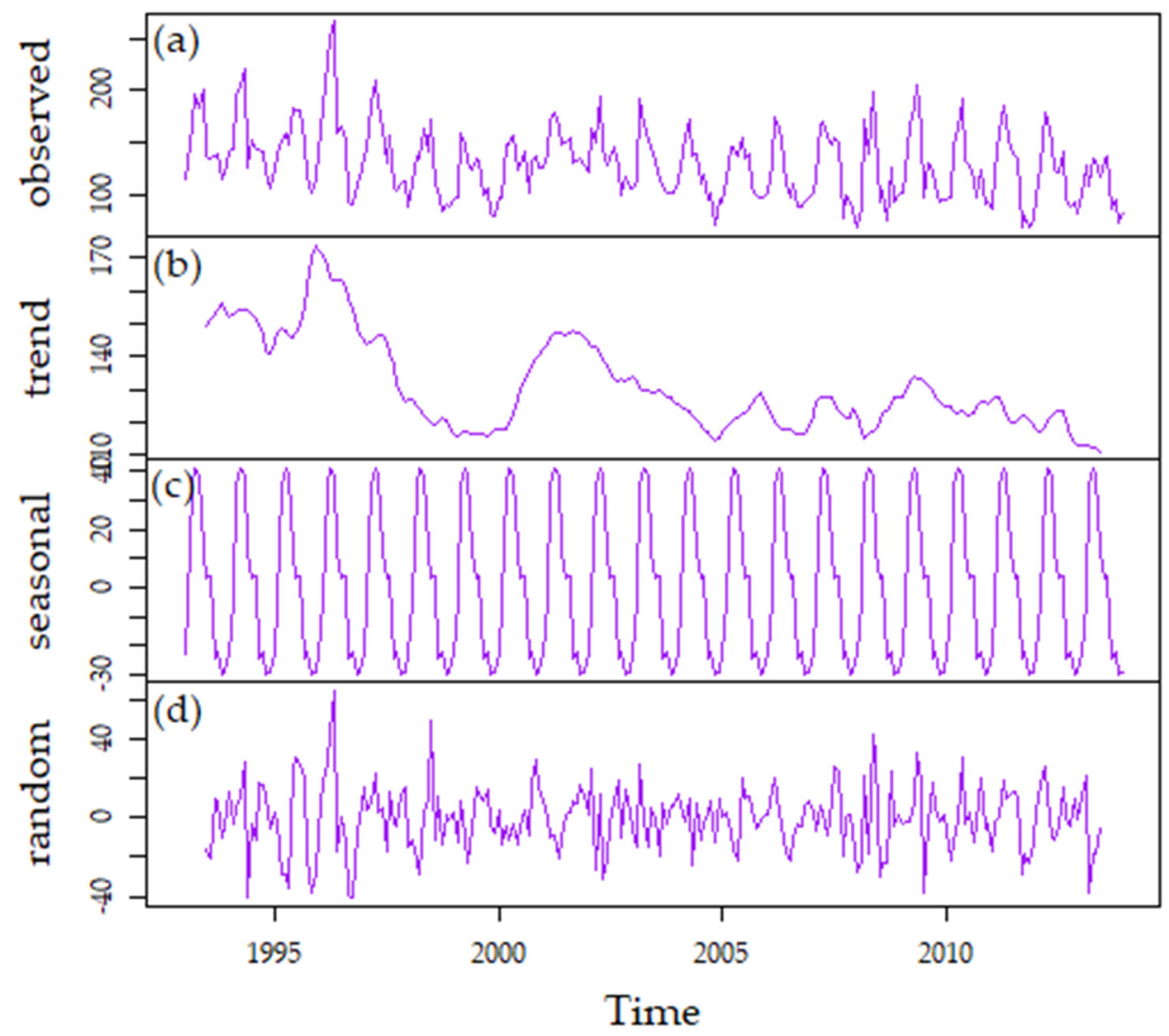

Figure 5. Decomposition of additive time series of monthly evaporation values recorded at the SMN weather station 21052 (1993 to 2013). The observed data is represented in the upper panel (a), while the next panels show the additive components [(b) long-term trend, (c) seasonal, and (d) random components].

Finally, the monthly temperature values were positively correlated with the monthly precipitation values $(r=0.61, p<0.05)$ and the monthly evaporation values $(r=0.53$, $p<0.05)$. Precipitation and evaporation did not show a significant correlation.

\subsection{The Aquatic Environment}

The lake presented a regular warm monomictic thermal pattern with a winter 3-month (January-March) mixing season and a prolonged stratification period. Consequently, the $\mathrm{Z}_{\mathrm{MIX}}$ varied between 9 and $15 \mathrm{~m}$ and the whole water column (Figure 6). The $\mathrm{Z}_{\mathrm{MIX}}$ was reduced drastically from the entire water column in March to the minimum in April, associated with the onset of the thermal stratification (early stratification) of the water column. Starting in April, the mixed layer gradually and steadily increased until December (late stratification) to give way to the mixing season in January, when the lake was completely mixed again. The average $Z_{\text {MIX }}$ in 1993-1994 was wider $(35 \pm 19 \mathrm{~m}, 15-60 \mathrm{~m})$ than in 2003 $(30 \pm 20 \mathrm{~m}, 9-60 \mathrm{~m})$ and $2013(30 \pm 19 \mathrm{~m}, 9-60 \mathrm{~m})$. The average $Z_{\mathrm{EU}}$ in 1993-1994 (23 $\pm 7 \mathrm{~m}$, 14-35 m) was greater than in $2003(21 \pm 5 \mathrm{~m}, 13-30 \mathrm{~m})$ and $2013(22 \pm 5 \mathrm{~m}, 15-31 \mathrm{~m})$. The $Z_{\mathrm{EU}}$ increased gradually from the lowest values in January-March to November; in December, the $Z_{\mathrm{EU}}$ diminished to reach the lowest values in January-March (Figure 6). Consequently, two phases regarding the $\mathrm{Z}_{\mathrm{EU}}$ could be distinguished - a turbid water phase with lower values of $Z_{\mathrm{EU}}$ while the lake was mixing, and a clear water phase with higher $\mathrm{Z}_{\mathrm{EU}}$ values along the stratification period (Figure 6). 
(a)

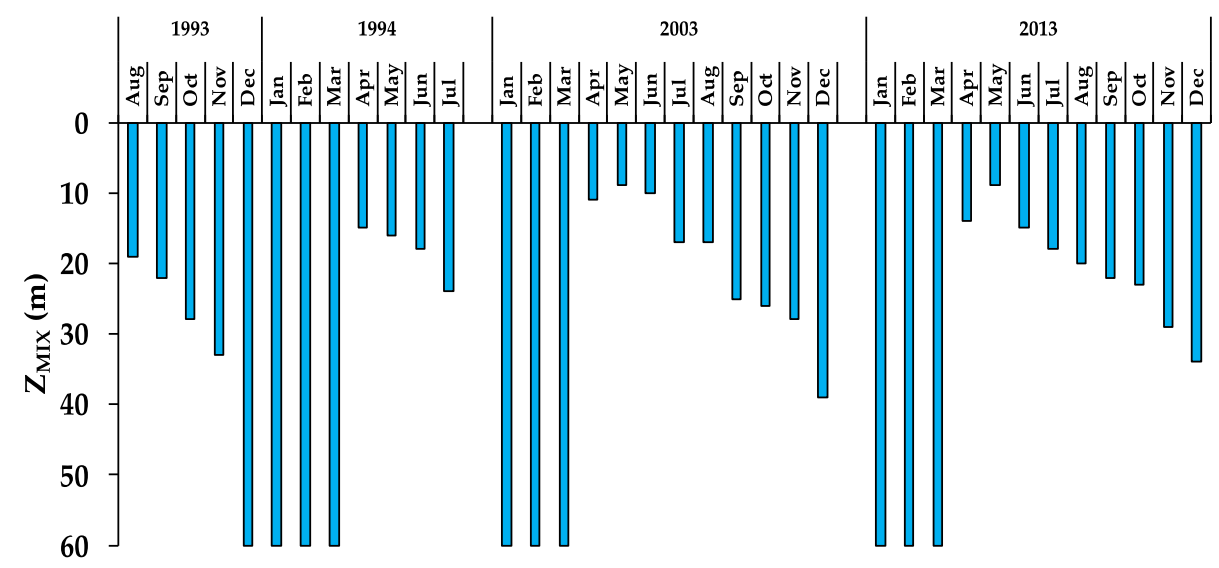

(b)

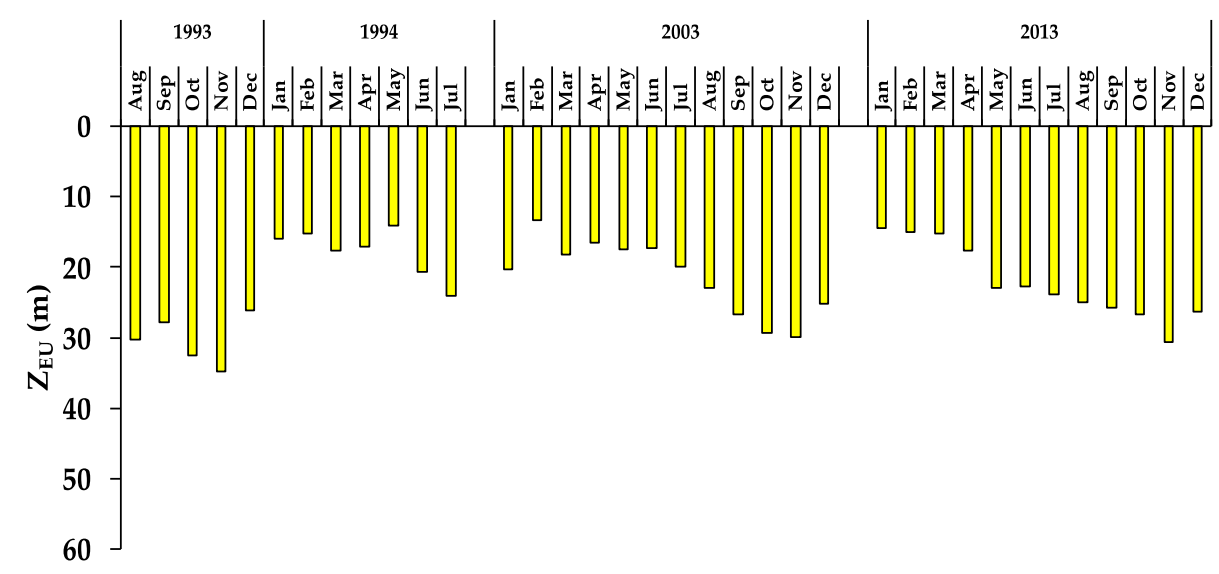

Figure 6. Temporal dynamics of the (a) mixing zone ( $\left.\mathrm{Z}_{\mathrm{MIX}}\right)$ and the (b) euphotic zone $\left(\mathrm{Z}_{\mathrm{EU}}\right)$ in Lake Alchichica. (Please note, the 1993-1994 cycle begins in August, while 2003 and 2013 in January).

January displayed the lowest water temperatures of the $\mathrm{Z}_{\mathrm{MIX}}\left(\mathrm{T}_{\mathrm{MIX}}\right)$. From January to March, the $\mathrm{T}_{\text {MIX }}$ slightly increased and then abruptly rose in April to reach the highest values in June. From then on, the $\mathrm{T}_{\mathrm{MIX}}$ descended to reach the lowest values in December. The $\mathrm{T}_{\mathrm{MIX}}$ was slightly colder in $1993-1994\left(17.1 \pm 1.4{ }^{\circ} \mathrm{C}, 15.0-18.7^{\circ} \mathrm{C}\right)$ than in 2003 $\left(17.5 \pm 2.1^{\circ} \mathrm{C}, 14.5-20.6^{\circ} \mathrm{C}\right)$ and $2013\left(17.6 \pm 1.9^{\circ} \mathrm{C}, 14.9-19.9^{\circ} \mathrm{C}\right)$, which turned out to be similar (Figure 7). The dissolved oxygen concentration in the $\mathrm{Z}_{\mathrm{MIX}}\left(\mathrm{DO}_{\mathrm{MIX}}\right)$ was high, close to saturation (i.e., $6.5 \mathrm{mg} \mathrm{L}^{-1}=100 \%$ SAT). The lowest $\mathrm{DO}_{\mathrm{MIX}}$ values were found during the mixing season (January to March), when the anoxic water of the hypolimnion mixed with the oxic water of the epilimnion. From then on, the $\mathrm{DO}_{\mathrm{MIX}}$ increased to reach the highest concentrations along the stratification to diminish by the end of the year. The average $\mathrm{DO}_{\mathrm{MIX}}$ increased from the lowest concentration in 1993-1994 $\left(5.3 \pm 1.1 \mathrm{mg} \mathrm{L}^{-1}\right.$, 3.9-6.7 $\left.\mathrm{mg} \mathrm{L}^{-1}\right)$ to $2003\left(5.9 \pm 0.8 \mathrm{mg} \mathrm{L}^{-1}, 4.5-6.8 \mathrm{mg} \mathrm{L}^{-1}\right)$ and $2013\left(6.4 \pm 1.4 \mathrm{mg} \mathrm{L}^{-1}\right.$, 3.6-8.0 $\mathrm{mg} \mathrm{L}^{-1}$ ) (Figure 7). 
(a)

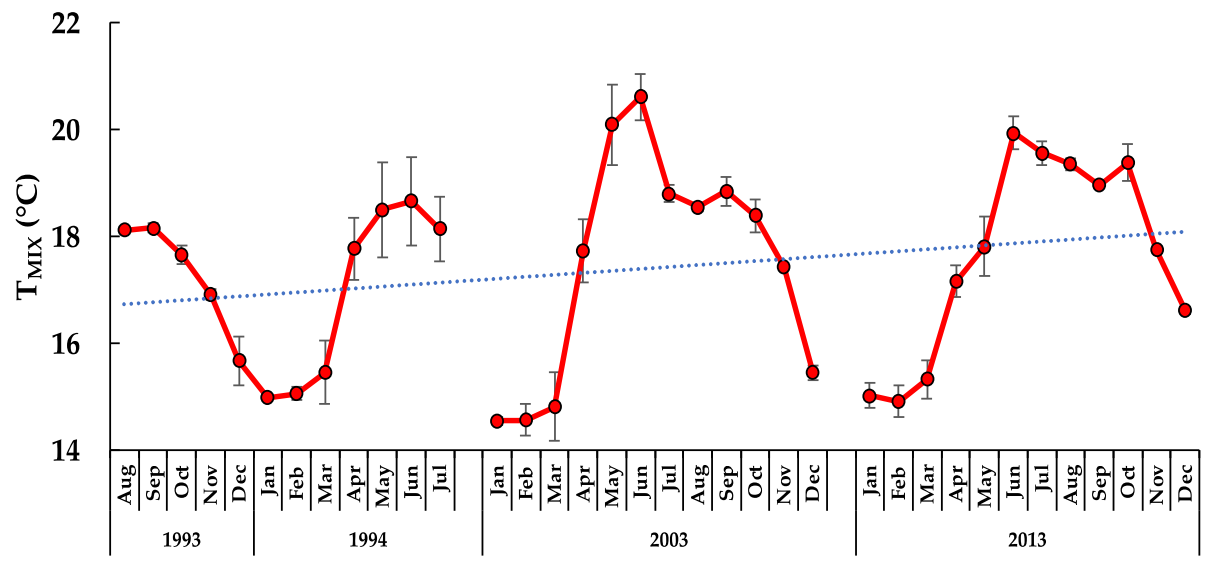

(b)

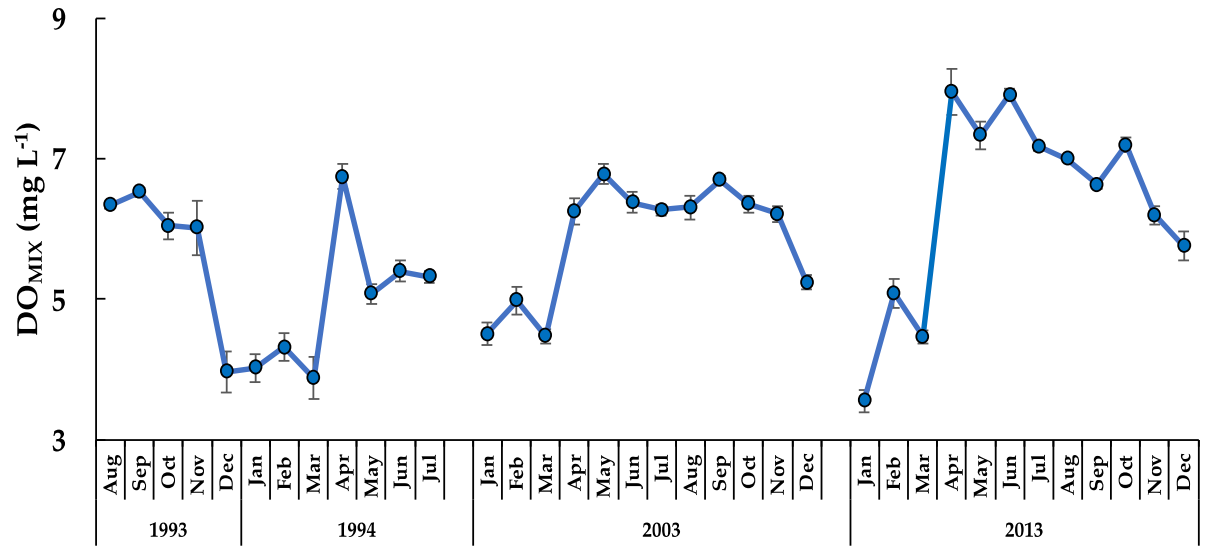

Figure 7. Temporal dynamics of the mixing zone (a) temperature $\left(\mathrm{T}_{\mathrm{MIX}}\right)$ and (b) dissolved oxygen

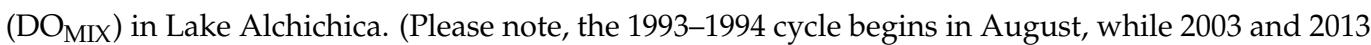
in January).

The water-column integrated Chl- $a$ concentration averaged $190 \pm 102 \mathrm{mg} \mathrm{m}^{-2}$ (93-434 mg m$\left.{ }^{-2}\right)$ in 1993-1994, $155 \pm 74 \mathrm{mg} \mathrm{m}^{-2}\left(84-302 \mathrm{mg} \mathrm{m}^{-2}\right)$ in 2003, and $200 \pm 176 \mathrm{mg}$ $\mathrm{m}^{-2}$ (49-514 $\mathrm{mg} \mathrm{m}^{-2}$ ) in 2013. The Chl-a concentration displayed an approximately regular seasonal pattern, with higher concentrations during the mixing season (January-March), the onset of the stratification (April-May), and the well-established stratification (SeptemberOctober). The magnitude of the Chl- $a$ concentration peaks differed among the three annual cycles (Figure 8).

The Chl- $a$ large fraction (LChl- $a, \geq 2 \mu \mathrm{m}$ ) dominated most of the time (83\%), while the Chl- $a$ small fraction (SChl- $a,<2 \mu \mathrm{m}$ ) rarely became dominant (17\%). The LChl- $a$ was $69 \pm 20 \%(35-95 \%)$ in 1993-1994, $75 \pm 19 \%(26-95 \%)$ in 2003 , and $76 \pm 13 \%(39-88 \%)$ in 2013. The temporal dynamics of both fractions largely differed seasonally and among annual cycles. The LChl- $a$ closely followed the TChl- $a$, while the SChl- $a$ was different, particularly in 1993-1994 (Figure 8). 
(a)

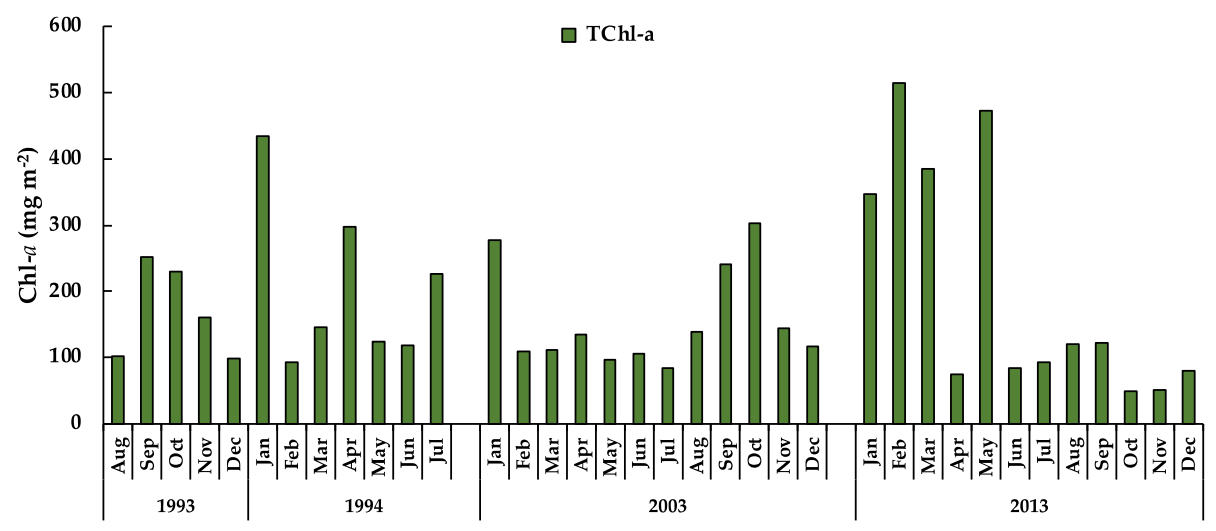

(b)

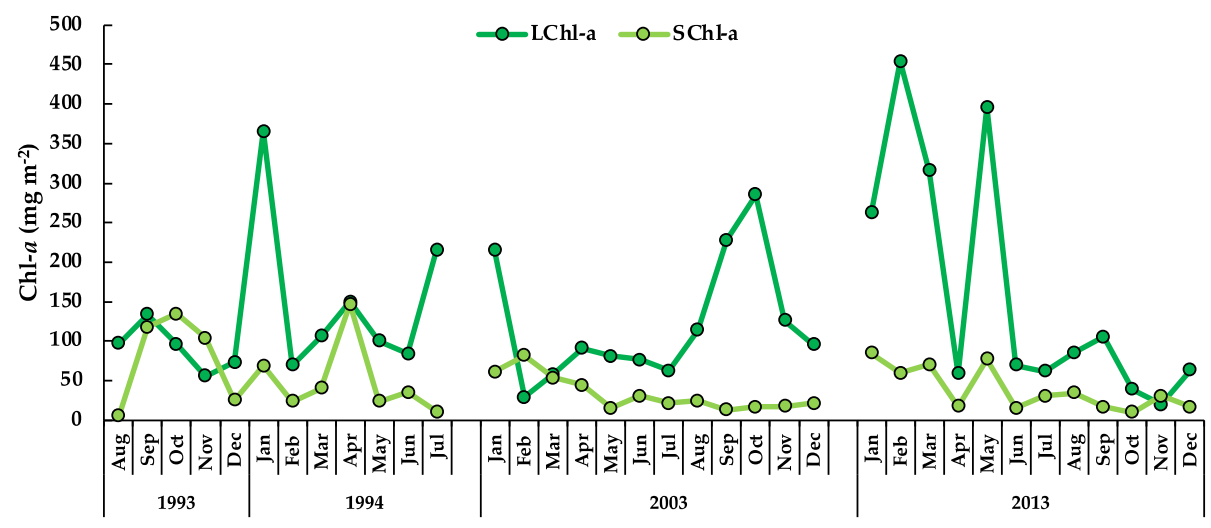

Figure 8. Temporal dynamics of the total water-column (a) integrated chlorophyll $a$ concentration (Chl- $a$ ) and (b) size-fractionated (large Chl- $a \geq 2 \mu \mathrm{m}$ and small Chl- $a<2 \mu \mathrm{m}$ ) in Lake Alchichica. (Please note, the 1993-1994 cycle begins in August, while 2003 and 2013 in January).

\subsection{The Planktonic Community}

\subsubsection{The Phytoplankton}

There were seven main phytoplankton species dwelling in Lake Alchichica-Cyclotella alchichicana Oliva, Lugo, Alcocer and Cantoral-Uriza, 2006; C. choctawhatcheeana Prasad, 1990; Chaetoceros elmorei Boyer, 1914; Nodularia aff. spumigena Mertens ex Bornet and Flahault, 1888; Oocystis submarina Lagerheim, 1886; O. parva West and G.S. West, 1898; Monoraphidium minutum Naegeli Komárková-Legnerová, 1969.

Regarding abundance, M. minutum, O. parva and N. aff. spumigena were dominant $(\approx 82 \%$ of total abundance). Concerning biovolume, C. alchichicana and N. aff. spumigena were dominant ( $\approx 93 \%$ of total biovolume). There were variations in the individual contribution, per species, to the abundance and biovolume among the three periods (Figure 9); however, the dominant species remained the same. M. minutum dominated numerically in 1993-1994 and 2003, while O. parva and N. aff. spumigena dominated in 2013. Differently, the biovolume was dominated in the three periods by the large $(35-63 \mu \mathrm{m})$ C. alchichicana.

The abundance averaged $1.35 \times 10^{11} \pm 1.56 \times 10^{11}$ cell m${ }^{-2}\left(2.76 \times 10^{10}-5.43 \times 10^{11}\right.$ cell m $\left.{ }^{-2}\right)$ in 1993-1994, $2.21 \times 10^{11} \pm 1.66 \times 10^{11}$ cell m$^{-2}\left(8.17 \times 10^{10}-5.93 \times 10^{11}\right.$ cell m$\left.^{-2}\right)$ in 2003 , and $9.82 \times 10^{10} \pm 1.17 \times 10^{11}$ cell m${ }^{-2}\left(8.00 \times 10^{9}-4.04 \times 10^{11}\right.$ cell m$\left.^{-2}\right)$ in 2013 . The phytoplankton abundance in 2003 was between 1.6 and 2.2 times larger than in 1993-1994 and 2013, respectively $(\mathrm{K}=14.48, p<0.001 ; 2013>1993-1994,2003)$. 


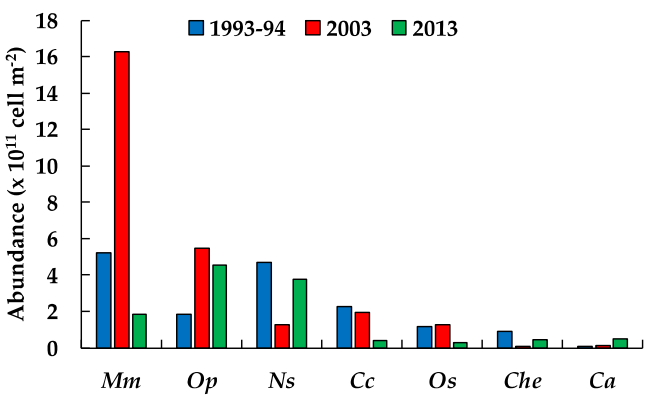

(a)

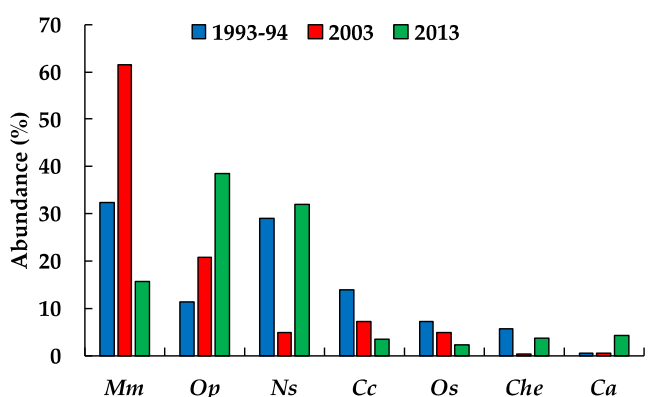

(b)

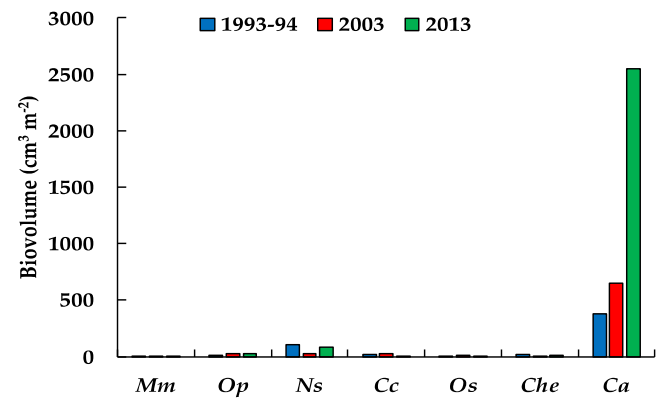

(d)

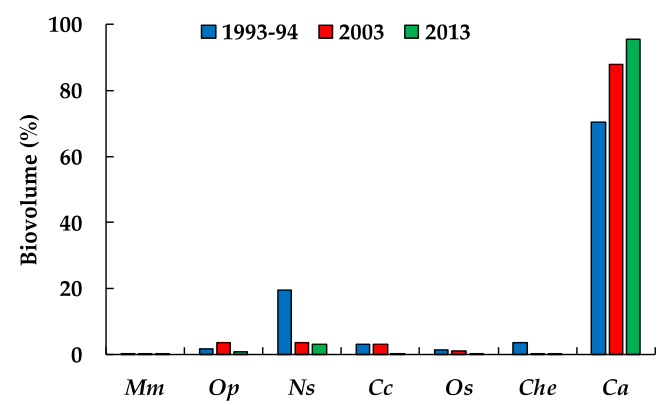

Figure 9. Per species contribution to absolute (a) and relative (c) abundance and absolute (b) and relative (d) biovolume of the seven main phytoplankton species in Lake Alchichica in the 3 annual cycles. (Mm: Monoraphidium minutum, Op: Oocystis parva, Ns: Nodularia aff. spumigena, Cc: Cyclotella choctawhatcheeana, Os: Oocystis submarina, Che: Chaetoceros elmorei, Ca: Cyclotella alchichicana).

There were three abundance peaks (i.e., above the annual average) in 1993-1994January, April (the largest), and June-July (Figure 10). C. choctawhatcheeana and M. minutum comprised the January peak, N. aff. Spumigena, the April peak, and M. minutum, O. parva, and O. submarina, the June-July peak. In 2003, two peaks were observed-January-February (the largest) and December (Figure 10). M. minutum comprised the January-February peak, and M. minutum, C. choctawhatcheeana, O. parva, and O. submarina, the December peak. Lastly, in 2013, there were two peaks-January-February and May-June (the largest) (Figure 11). M. minutum and O. parva comprised the January-February peak, and N. aff. spumigena and O. parva comprised the May-June peak.

The biovolume averaged $44.4 \pm 39.3 \mathrm{~cm}^{3} \mathrm{~m}^{-2}\left(5.4-117.9 \mathrm{~cm}^{3} \mathrm{~m}^{-2}\right)$ in 1993-1994, $61.9 \pm 37.7 \mathrm{~cm}^{3} \mathrm{~m}^{-2}\left(22.7-143.2 \mathrm{~cm}^{3} \mathrm{~m}^{-2}\right)$ in 2003 , and $222.5 \pm 197.4 \mathrm{~cm}^{3} \mathrm{~m}^{-2}(40.8-$ $574.0 \mathrm{~cm}^{3} \mathrm{~m}^{-2}$ ) in 2013. The phytoplankton biovolume in 2013 was between 3.6 and 5.0 times larger than 2003 and 1993-1994, respectively.

There were three abundance peaks (i.e., above the annual average) in 1993-1994September-October, April (the largest), and June (Figure 11). C. alchichicana comprised the September-October and June peaks, while N. aff. Spumigena, the April peak. In 2003, there were two peaks - in August and in October-December (the largest) (Figure 12). Both peaks were composed of C. alchichicana. Lastly, in 2013, there were two peaks-JanuaryMarch (the largest) and August (Figure 11). Once again, both peaks were composed of C. alchichicana. 
(a)
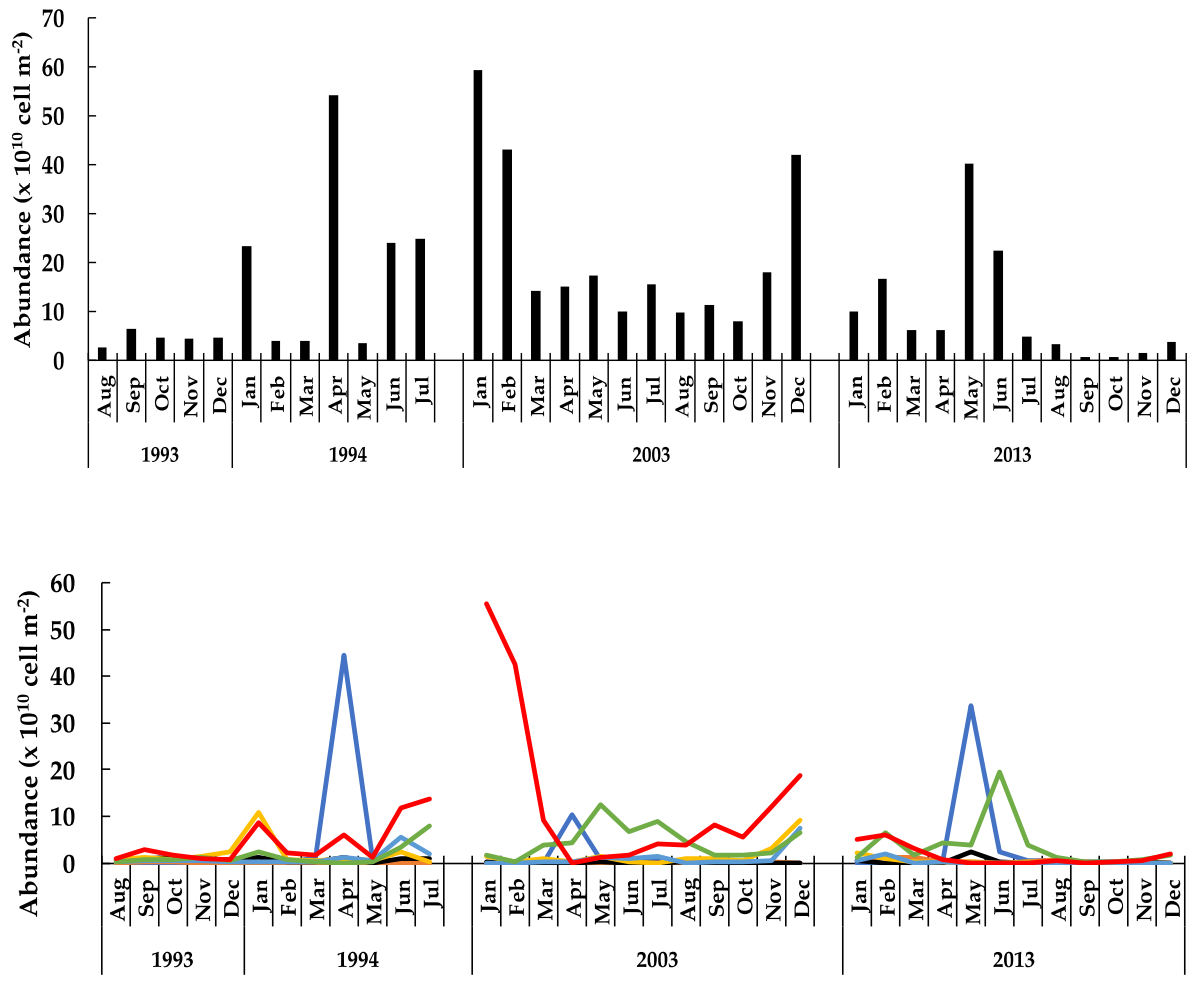

(b)

Figure 10. Temporal dynamics of (a) total phytoplankton and (b) per species abundance in Lake Alchichica during 1993-1994, 2003, and 2013. (Mm: Monoraphidium minutum, Op: Oocystis parva, Ns: Nodularia aff. spumigena, Cc: Cyclotella choctawhatcheeana, Os: Oocystis submarina, Che: Chaetoceros elmorei, Ca: Cyclotella alchichicana).

(a)

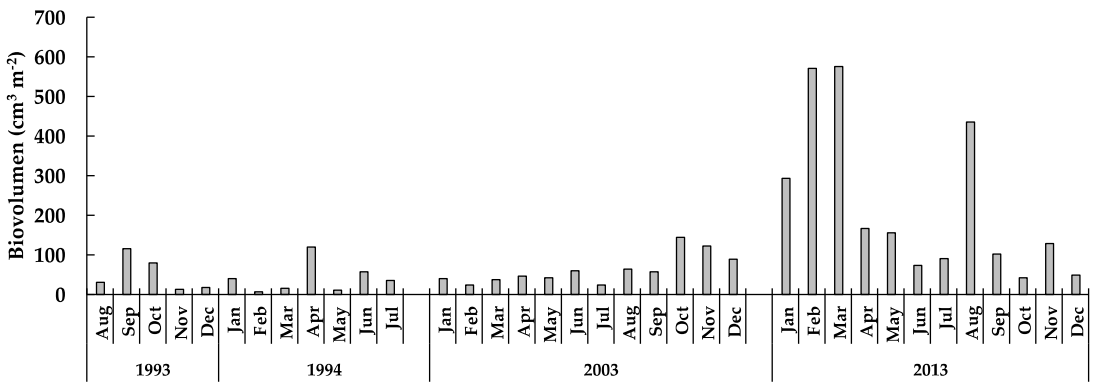

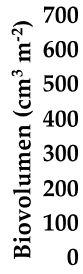

(b)

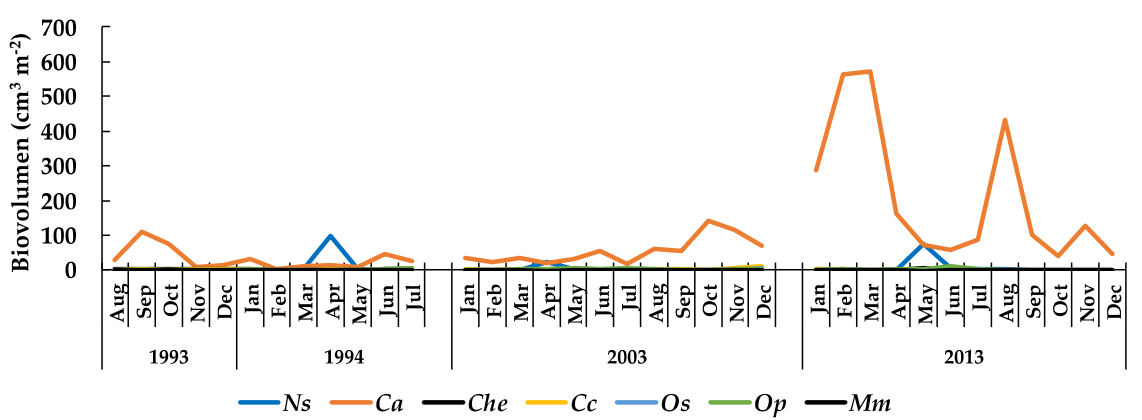

Figure 11. Temporal dynamics of (a) total phytoplankton and (b) per species biovolume in Lake Alchichica during 1993-1994, 2003, and 2013. (Mm: Monoraphidium minutum, Op: Oocystis parva, Ns: Nodularia aff. spumigena, Cc: Cyclotella choctawhatcheeana, Os: Oocystis submarina, Che: Chaetoceros elmorei, Ca: Cyclotella alchichicana). 


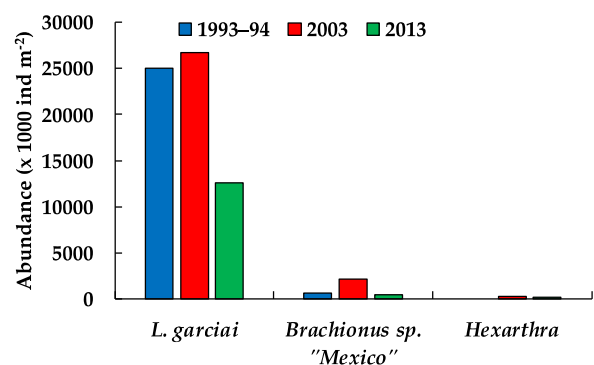

(a)

(c)

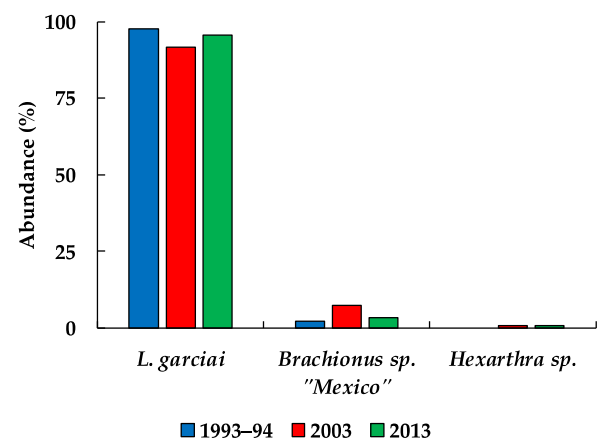

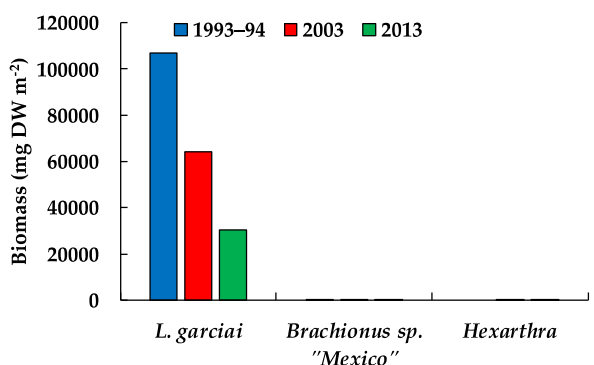

(b)

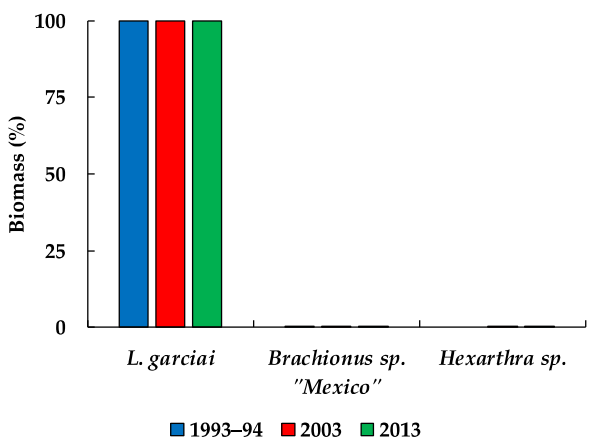

Figure 12. Per species contribution to the (a) absolute and (c) relative abundance, and (b) absolute and (d) relative biomass of the three zooplankton species in Lake Alchichica in the 3 annual cycles. (DW: dry weight).

The temporal dynamics of the phytoplankton abundance and biomass were irregular. The phytoplankton abundance peak timing matched in January or January-February of the three years, and in June or June-July of just two years, while the phytoplankton biovolume peak timing coincided only in August and October in two out of the three years.

\subsubsection{The Zooplankton}

There were three zooplankton species dwelling in Lake Alchichica-the calanoid copepod Leptodiaptomus garciai Osorio-Tafall, 1942 and two rotifers, one of the Brachionidae family, Brachionus sp., related to B. plicatilis Müller, 1786 complex, and one of the Hexarthridae family, Hexarthra sp., related to H. jenkinae De Beauchamp, 1932 complex. Mills et al. [44] recognized the Brachionus inhabiting Lake Alchichica as a different species not yet described, but provisionally designated as Brachionus sp. "Mexico".

L. garciai was dominant regarding both total abundance $(\approx 95 \%$ of total abundance $)$ and total biomass $(\approx 99.9 \%$ of total biomass). There were variations in the per species contribution to abundance and biomass among the three periods (Figure 12); however, the dominant species, L. garciai, remained the same, followed, well below, by B. sp. "Mexico", and lastly, by Hexarthra sp.

The abundance averaged $2137 \pm 1671$ ind $\mathrm{m}^{-2}\left(213-5603\right.$ ind $\left.\mathrm{m}^{-2}\right)$ in 1993-1994

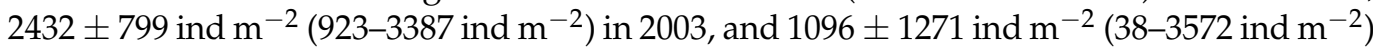
in 2013. The zooplankton abundance in 2003 was between 1.1 and 2.2 times larger than in 1993-1994 and 2013, respectively. There was an extended abundance peak (i.e., above the annual average) in 1993-1994 in January-July (Figure 13). In 2003, there were three peaks-January-March, July-August (the largest), and December (Figure 14). Lastly, in 2013, there were three peaks-January-February, April (the largest), and June (Figure 13). Leptodiaptomus garciai comprised all abundance peaks in the three periods. 


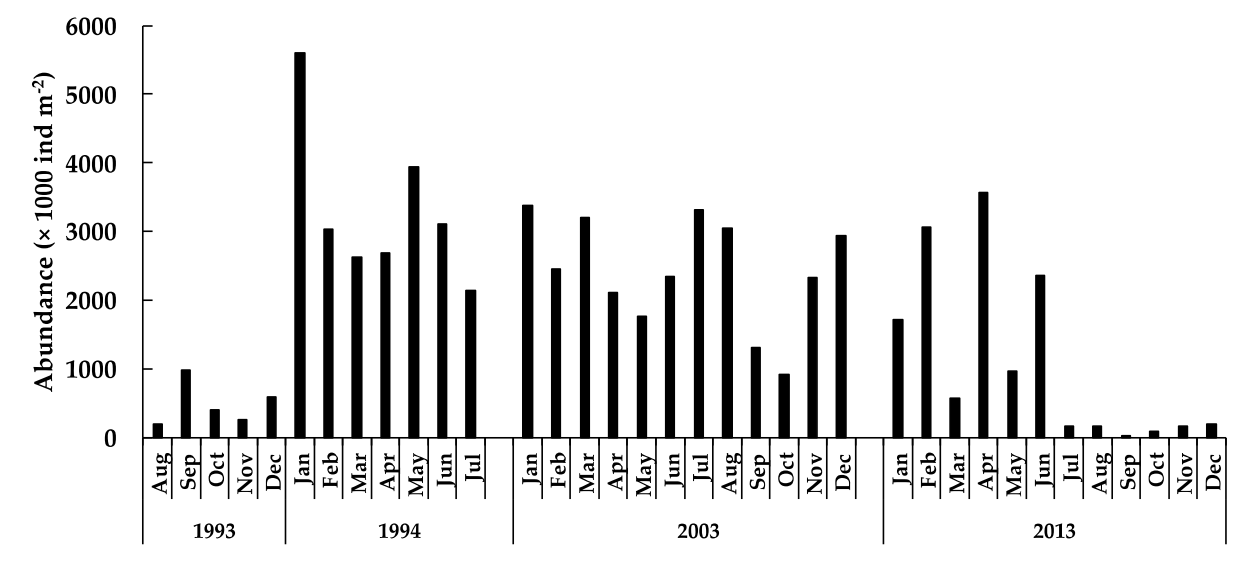

(a)

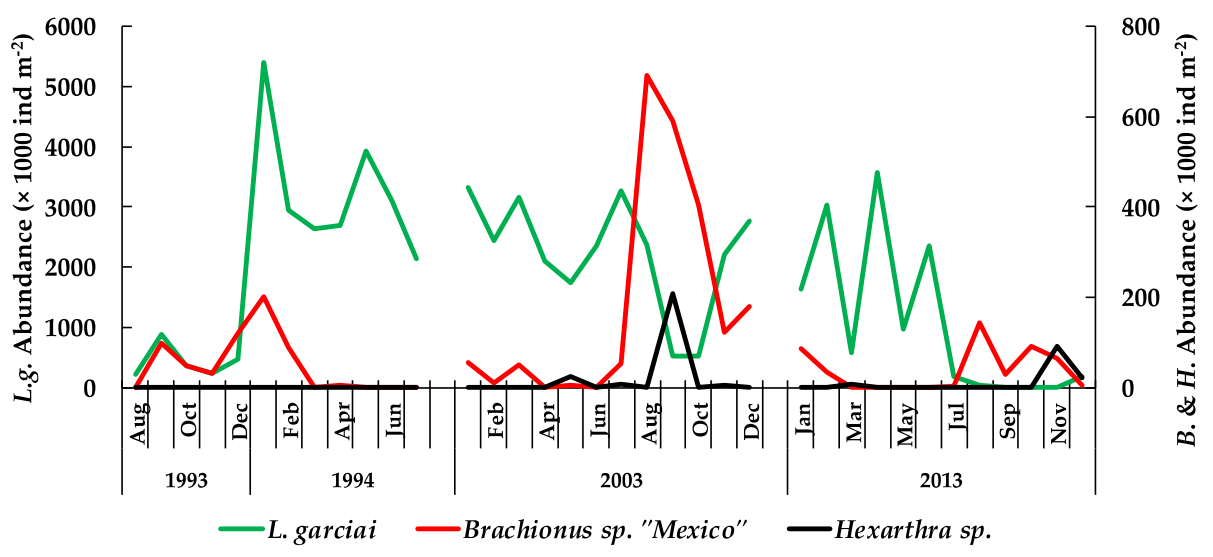

(b)

Figure 13. Temporal dynamics of (a) total zooplankton and (b) per species abundance in Lake Alchichica during 1993-1994, 2003, and 2013. (L.g. = Leptodiaptomus garciai, B. = Brachionus sp. "Mexico", H. = Hexarthra sp.).

The biomass averaged $8903 \pm 7865 \mathrm{mg} \mathrm{DW} \mathrm{m}^{-2}\left(999-21,341 \mathrm{mg} \mathrm{DW} \mathrm{m}^{-2}\right)$ in 1993$1994,5354 \pm 3625 \mathrm{mg} \mathrm{DW} \mathrm{m}^{-2}\left(641-11,152 \mathrm{mg} \mathrm{DW} \mathrm{m}^{-2}\right)$ in 2003, and $2534 \pm 3466 \mathrm{mg}$ DW m ${ }^{-2}\left(13-10,826 \mathrm{mg} \mathrm{DW} \mathrm{m}^{-2}\right)$ in 2013. The zooplankton biomass in 1993-1994 was between 1.7 and 3.5 times larger than in 2003 and 2013, respectively. There was an extended biomass peak (i.e., above the annual average) in 1993-1994-January-June (Figure 14). In 2003, there were two peaks-February-April and June-July (the largest) (Figure 14). Lastly, in 2013, there were two peaks-March and April-June (the largest) (Figure 15). Leptodiaptomus garciai comprised all biomass peaks in the three periods.

The temporal dynamics of the zooplankton abundance and biomass were irregular. The zooplankton abundance peak timing matched in January-February in the three years, and in March-April and June-July in just two years, while the zooplankton biomass peak timing coincided only in February, April, and June in the three years, and in March in two years. The Leptodiaptomus garciai population structure varied widely seasonally and interannually. Juvenile (i.e., nauplii and copepodites) abundance comprised $30.1 \pm 25.4 \%$ in $1993-1994,76.5 \pm 22.6 \%$ in 2003 , and $82.7 \pm 15.2 \%$ in 2013 , whereas adults constituted $69.9 \pm 25.4 \%$ in $1993-1994,23.5 \pm 22.6 \%$ in 2003 , and $17.3 \pm 15.2 \%$ in 2013 (Figure 15). The abundance of adult females comprised $71.4 \pm 17.8 \%$ in $1993-1994,54.0 \pm 8.0 \%$ in 2003 , and $41.4 \pm 32.2 \%$ in 2013 , whereas the abundance of adult males constituted $28.6 \pm 17.8 \%$ in $1993-1994,46.0 \pm 8.0 \%$ in 2003 , and $58.6 \pm 32.2 \%$ in 2013 . Adult male-female rates were $0.4: 1$ (1993-1994), 0.9:1 (2003), and 1.4:1 (2013) (Figure 15). Nauplii contributed to the abundance of juveniles with $62.2 \pm 27.6 \%$ in $1993-1994,52.1 \pm 26.4 \%$ in 2003 , and $52.4 \pm 36.7 \%$ in 
2013 , whereas copepodites constituted $29.5 \pm 21.5 \%$ in $1993-1994,47.9 \pm 26.4 \%$ in 2003 , and $47.6 \pm 36.7 \%$ in 2013 (Figure 15).

(a)

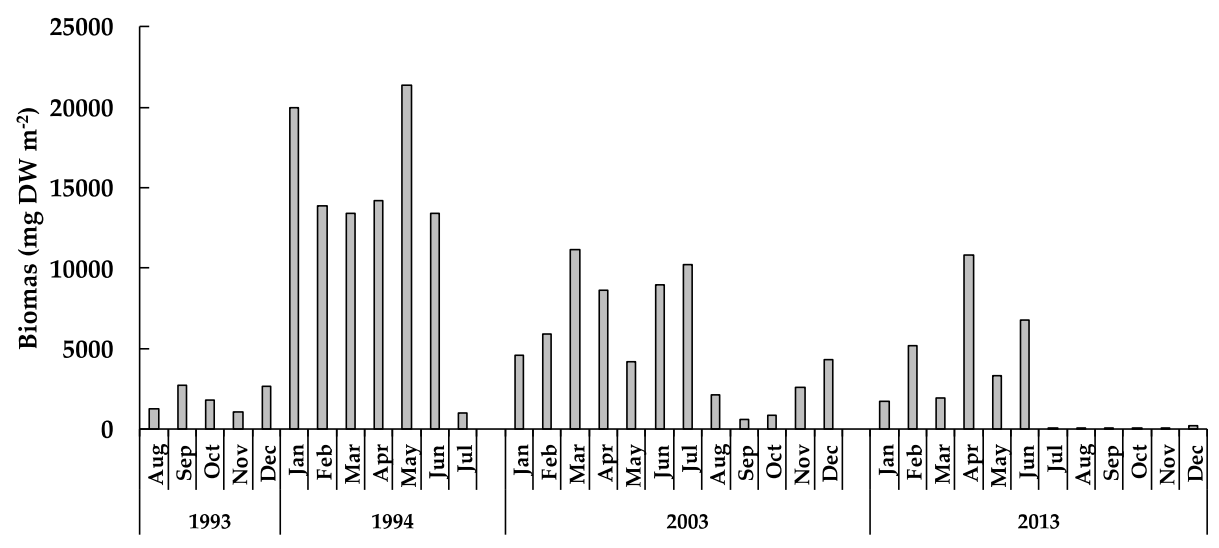

(b)

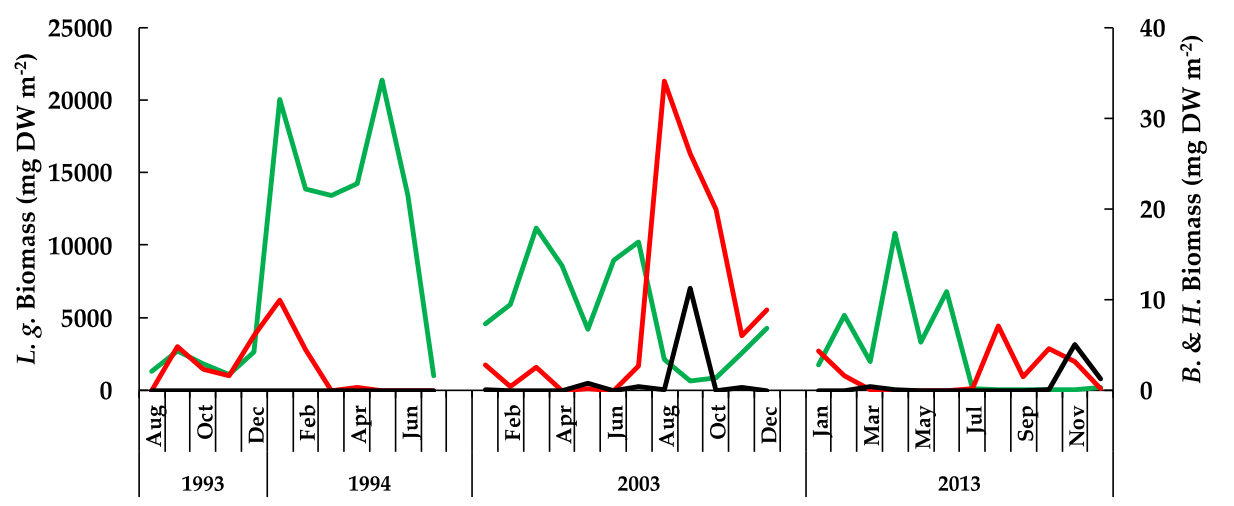

Figure 14. Temporal dynamics of the (a) total zooplankton and (b) per species biomass in Lake Alchichica during 1993-1994, 2003, and 2013. (DW: dry weight). (L.g. = Leptodiaptomus garciai, B. = Brachionus sp. "Mexico", H. = Hexarthra sp.).

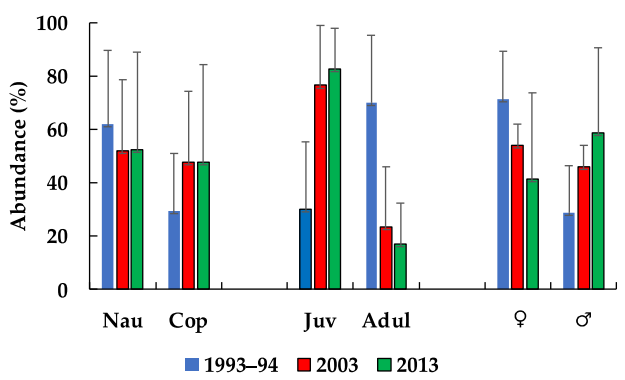

(a)

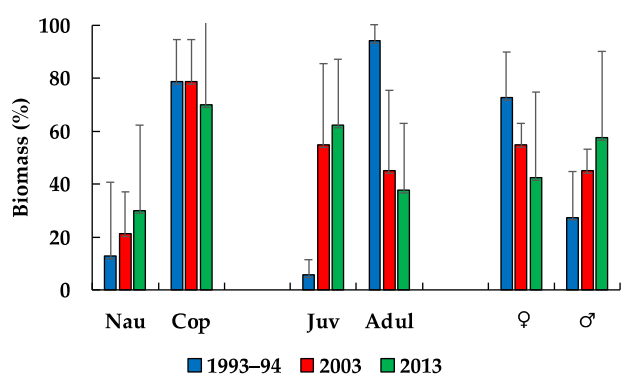

(b)

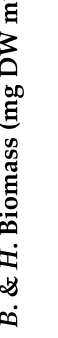


1993-1994, $21.3 \pm 15.9 \%$ in 2003, and $30.1 \pm 32.1 \%$ in 2013, whereas the copepodite biomass constituted $78.8 \pm 37.2 \%$ in $1993-1994,78.7 \pm 37.2 \%$ in 2003 , and $69.9 \pm 32.1 \%$ in 2013 (Figure 15).

\subsubsection{Long-Term Patterns, Correlations, and Trends}

Lake Alchichica displayed environmental regularity (e.g., [22,52]) driven by the warm monomictic thermal pattern characteristic of deep, tropical lakes [53]. The observed recurrent limnological pattern of Lake Alchichica could be summarized as follows. During the winter mixing season (maximum $\mathrm{Z}_{\mathrm{MIX}}$ ), the water column remained quite homogeneous with the lowest temperatures and well-oxygenated waters. Mixing represents the turbid water phase (lowest $\mathrm{Z}_{\mathrm{EU}}$ ) with high Chl- $a$ concentrations (biogenic turbidity). The mixing season was dominated numerically by the small chlorophyte Monoraphidium minutum, while the large diatom Cyclotella alchichicana dominated in biomass (i.e., winter diatom bloom). The calanoid copepods dominated numerically and in biomass during the mixing season.

At the onset of the stratification, when the $Z_{\mathrm{MIX}}$ was low, the temperature increased, as well as the $\mathrm{Z}_{\mathrm{EU}}$, and the cyanoprokaryota Nodularia aff. spumigena bloomed and dominated, numerically (along with Oocystis parva) and in biomass. While the $N$. aff. spumigena bloomed, calanoid copepods also increased numerically and in biomass.

The stratification period corresponded to the clear water phase (highest $Z_{\mathrm{EU}}$ ), with a low Chl- $a$ concentration in the $Z_{\mathrm{MIX}}$. The $\mathrm{Z}_{\mathrm{MIX}}$ was warm and well-oxygenated. Through the extended stratification season, the $Z_{\mathrm{MIX}}$ and $\mathrm{Z}_{\mathrm{EU}}$ broadened. Sometimes, between June and July, M. minutum increased numerically, along with the small chlorophyte O. parva. Approximately from September to November, a deep chlorophyll maximum (DCM) developed at the metalimnion. Along with the DCM formation, the calanoid copepods also increased numerically and in biomass.

Although most environmental variables did not differ among periods, there were significant differences (Kruskal-Wallis) in water temperature between the colder 1993-1994 and the warmer 2003 and 2013. The water temperature dynamics match the air temperature in that there was not an increasing trend between 1993-1994 and 2013, but a similar and slight increase in temperature from 2002 to 2013.

The significant and inverse correlation between the $\mathrm{Z}_{\mathrm{EU}}$ and the abundance and biomass of adult male copepods $(\rho=-0.687, p=0.003)$, the total abundance and biomass of copepods ( $\rho=-0.682, p=0.004)$, and the total zooplankton (copepods + rotifers) biomass $(\rho=-0.681, p=0.004)$ is related to the biogenic origin of turbidity in Lake Alchichica. The turbid water phase (i.e., low $\mathrm{Z}_{\mathrm{EU}}$ ) was found during the mixing period, when the winter diatom bloom developed. The high phytoplankton production was coupled with a higher zooplankton abundance and biomass. Differently, the clear-water phase (i.e., high $\mathrm{Z}_{\mathrm{EU}}$ ) developed along the stratification period, when the phytoplankton production was low, and the zooplankton abundance and biomass were diminished. The negative correlation $(\rho=-0.7171, p<0.001)$ between the $Z_{\mathrm{MIX}}$ and Nodularia aff. spumigena abundance and biomass is explained by the set of environmental conditions (e.g., increased light availability, higher temperature, water column stability, and nutrient deficiency, particularly nitrogen) present at the early stratification, with the $\mathrm{Z}_{\mathrm{MIX}}$ at the minimum, favouring $N$. aff. spumigena to bloom.

There was a significant positive correlation between the copepod nauplii larvae abundance and the small chlorophyte $M$. minutum abundance and biomass $(\rho=0.7171, p<0.001)$, and between the copepod's larvae biomass and the biomass of the small chlorophyte O. parva $(\rho=0.6883, p<0.001)$. The small chlorophytes most likely constitute a crucial component of the copepod's nauplii larvae diet. This contrasts with the significant negative relationship between the abundance and biomass of L. garciai females $(\rho=-0.620, p=0.007$ and $\rho=-0.610, p=0.011$ ) and the abundance and biomass of the total adult copepods $(\rho=-0.574, p=0.03$ and $\rho=-0.582, p=0.03)$ with $C$. alchichicana. The large size of the diatom makes it inedible for the copepods, even for those in the adult stage [46]. Finally, 
the strong positive relationship $(\rho=0.9181, p<0.001)$ between the total abundance of the phytoplankton and the abundance of $C$. alchichicana indicates their similar seasonal and interannual dynamics.

The trend analyses of biological data are presented in Table 1. Several phytoplankton species, mostly of a small or medium cell size, decreased over the years. In contrast, C. alchichicana, the phytoplankton biomass dominant species, increased its abundance and biomass, causing the same trend for the total phytoplankton biomass. In the case of zooplankton, the abundance of the adult stages of L. garciai, both males and females, decreased along with their biomass and the total zooplankton abundance and biomass (Table 1).

Table 1. Mann-Kendall test results for trend analyses of biological data. ( $\mathrm{S}=$ Mann-Kendall statistics. $\mathrm{Z}=$ normal value for significance determination. $p=$ probability).

\begin{tabular}{|c|c|c|c|c|c|}
\hline & Variable & $\mathbf{S}$ & $\mathbf{Z}$ & $p$ & Trend \\
\hline \multirow{5}{*}{ Phytoplankton } & C. alchichicana abundance and biomass & 284 & 3.8547 & 0.00001 & Increase \\
\hline & Chaetoceros elmorei abundance and biomass & -161 & 2.1884 & 0.028 & Decrease \\
\hline & C. choctawhatcheeana abundance and biomass & -255 & 3.46 & 0.005 & Decrease \\
\hline & O. submarina abundance and biomass & -202 & 2.7545 & 0.0058 & Decrease \\
\hline & Total phytoplankton abundance and biomass & 274 & 3.7185 & 0.0002 & Increase \\
\hline \multirow{8}{*}{ Zooplankton } & L. garciai female abundance & -272 & 3.7009 & 0.0002 & Decrease \\
\hline & L. garciai male abundance & -216 & 2.935 & 0.0033 & Decrease \\
\hline & Total L. garciai adults & -265 & 3.6023 & 0.0003 & Decrease \\
\hline & Total copepods abundance & -144 & 1.4608 & 0.049 & Decrease \\
\hline & L. garciai female biomass & -274 & 3.7261 & 0.0001 & Decrease \\
\hline & L. garciai male biomass & -321 & 3.0032 & 0.0026 & Decrease \\
\hline & Adult copepods biomass & -266 & 3.6189 & 0.0029 & Decrease \\
\hline & Total copepods biomass & -226 & 3.0717 & 0.0021 & Decrease \\
\hline
\end{tabular}

\section{Discussion}

Lake Alchichica displayed seasonal and interannual variability during the studied period. The seasonal, recurrent limnological occurrences were clearly associated with the warm monomictic thermal pattern, as has been reported previously (e.g., [54]). Differently, the interannual variability was most likely associated with variations in the study area's global atmospheric circulation traits (e.g., ENSO). The authors of [55] found that Lake Alchichica responded to ENSO events through environmental (e.g., warmer epilimnetic waters) and biological (e.g., a modest cyanobacterial bloom) variability.

The temperature correlated to the precipitation $(\mathrm{r}=0.6)$ and to all the tested climate indices, suggesting that the ENSO, PDO, and AMO could have influenced the thermal regime of the study area during 1993-2013. In particular, the identified warmer years (2004, 2008, and 2013) coincide with El Niño events, while the colder years (2006, 2009, and 2011) with La Niña events.

Precipitation had no statistically significant trend. The precipitation correlated to the SOI negatively, meaning that it increased during the "La Niña" events, following the report for southern Mexico [56]. On the other hand, precipitation was positively correlated to the AMO, meaning that negative phases of this oscillation were associated with drier conditions. The latter has been documented for the last 400 years in a $\delta^{18} \mathrm{O}$ record in central Mexico [57].

Evaporation had a statistically significant negative trend. Evaporation was positively correlated to temperature $(r=0.5)$. However, the fact that temperature did not have a significant decreasing trend suggests that other factors must explain the evaporation decrease. Evaporation correlated positively $(r=0.3)$ with the PDO index, which decreased from 2000 to 2011. Therefore, the factors that caused the evaporation decrease could be related to changes in the sea surface temperature (SST) of the Pacific Ocean, as the PDO is a decadal mode of the spatial structure of the SST in the tropical Pacific [58-63]. 
We did not find the expected association between the temperature and evaporation increase and precipitation decrease related to climate change [64]. Differently, at least during the studied period, there seemed to exist an interannual variability of the meteorological variables controlled by the traits of the global atmospheric circulation that affect Central Mexico and the variability caused by the global climate phenomena, such as the ENSO, PDO, and AMO.

We found no statistically significant trends during the analysed period in this study (1993 to 2013 in air temperature and 1998-2013 in water temperature), but a slight increase in the air temperature from 2002 to 2013, which was not mirrored in the water temperature. However, by considering a longer meteorological dataset, Silva-Aguilera et al. (in prep.) found a statistically significant increase (Mann-Kendall test $\mathrm{S}=484, p<0.001$ ) of $0.02{ }^{\circ} \mathrm{C}_{\text {year }}{ }^{-1}$ through analysing the long-term (1966-2018) meteorological data recorded by the SMN-21052 weather station. In addition, Alcocer et al. (in preparation) found a statistically significant increase in the water temperature at (a) the $Z_{\text {MIX }}$ (Mann-Kendall test $\mathrm{S}=98, p=0.003$ ) of $0.04{ }^{\circ} \mathrm{C}$ year ${ }^{-1}$ and (b) the bottom layer of Lake Alchichica during the mixing season, when the lowest temperatures of $0.03{ }^{\circ} \mathrm{C}$ year ${ }^{-1}$ were recorded (Mann-Kendall test $S=91, p=0.011$ ) through analysing a long-term temperature record (1998-2018). A $0.02{ }^{\circ} \mathrm{C}_{\text {year }}{ }^{-1}$ increasing rate in air temperature corresponds with the Intergovernmental Panel on Climate Change (IPCC) report about a temperature increase of $0.5^{\circ} \mathrm{C}$ in 50 years $\left(0.01^{\circ} \mathrm{C}_{\text {year }}{ }^{-1}\right)$ being indicative of climate change [64]. In addition, ref. [9] mentioned that the lake surface water temperatures increased worldwide at an average rate of $0.34{ }^{\circ} \mathrm{C}$ decade ${ }^{-1}$; this is $0.034{ }^{\circ} \mathrm{C}_{\text {year }}{ }^{-1}$, which fits well what we found in Lake Alchichica.

Climate change can alter communities directly and indirectly by modifying the abundance, phenology, distribution, body size, life history, general, and the community structure, among other characteristics [65]. Michelutti et al. ([66]) already reported the ecological restructuring of tropical Andean lakes associated with warming. These changes can be transmitted through interspecific relationships in the food web, modifying the whole community [67]. Lake Alchichica displayed a phytoplankton successional pattern that conforms in some ways to what was described by [68] for tropical lakes but differs in others, such as the one found by [69] in Lake Titicaca. The order of appearance of taxa in the $Z_{\text {MIX, }}$ with diatoms dominating during the deep mixing, followed by cyanobacteria at the onset of the stratification, and finally, chlorophytes along with the stratification, is followed in Lake Alchichica.

The size class composition of phytoplankton and their availability to be consumed by zooplankton is a factor that can modify the interactions between climate change and plankton communities [70]. Lake Alchichica has a unique phytoplankton size composition dominated by cells $>40 \mu \mathrm{m}$ and, to a lesser extent, by cells $<10 \mu \mathrm{m}$. For their part, the copepods ( L. garciai) preferentially consume sizes of $<40 \mathrm{um}$ and the rotifers sizes of $<20 \mu \mathrm{m}$. This means that available food is scarce since, in addition, a part of the fraction of $<40 \mu \mathrm{m}$ is formed by colonies of cells with mucilaginous covers, which can also be inedible or indigestible by zooplankton [46].

Lake Alchichica displayed no species replacement of phytoplankton and zooplankton during the studied 20 years. The dominant (i.e., abundance and biomass) phytoplankton and zooplankton species composition remained the same. However, we identified an increasing trend in the phytoplankton and $C$. alchichicana abundance and biomass that could be responding to the temperature increment.

Saros and Anderson ([71]) cited higher abundances of Cyclotella species associated with global warming, while [72] mentioned the predominance of the small over the large size Cyclotella species. The increased thermal stratification associated with warming resulted in nutrient scarcity of the epilimnion favouring the small phytoplankton, which is more efficient for assimilating nutrients in low nutrient concentrations based on a higher surface-to-volume ratio. However, in Lake Alchichica, the large C. alchichicana increased in abundance and biomass, while the small C. choctawhatcheeana (size $8 \mu \mathrm{m}$ ) decreased. 
This apparent contradiction resides most likely in the edibility differences between the two species. While the large size C. alchichicana are inedible by the zooplankton, the small size C. choctawhatcheeana are consumed by both zooplanktonic groups, copepods, and rotifers. The authors of [71] found the top-down control selectively consumed the edible phytoplankton, favouring the large inedible phytoplankton. Such seems to be the case in Lake Alchichica, where the top-down control selectively consumed the small size, edible C. choctawhatcheeana, reducing its numbers and biomass while favouring the increase in numbers and biomass of the large size, inedible C. alchichicana, taking advantage of the available nutrients.

Considering that "a single species could not be used as a thermometer itself", and that a species responds indirectly to climate change, reacting to the growing conditions in the environment it inhabits, which in turn, can be affected by a combination of forcing factors [72], including global warming and anthropogenic impacts. Besides global warming, the nearby anthropogenic impacts (e.g., agricultural fertilizers) threaten Lake Alchichica with eutrophication [73]. However, despite the C. alchichicana biomass increasing trend, along with higher temperatures and the expected potential impact of agriculture on the lake's trophic status, the Chl- $a$ concentration did not differ between the three yearly cycles nor showed an increasing trend as expected. The answer to this apparent self-contradiction could be the role $C$. alchichicana plays, as nutrients sink into the lake's deep sediments.

The three most important primary production events in Lake Alchichica, the diatom (composed mostly of C. alchichicana) and cyanobacteria (i.e., N. aff. spumigena) blooms and the DCM (composed mostly of C. alchichicana), were driven by the warm monomictic thermal pattern [74]. C. alchichicana and N. aff. spumigena comprised most of Lake Alchichica's phytoplankton biomass. The large size of both species and the toxicity of the latter prevent their incorporation into the pelagic food web. C. alchichicana is mostly exported to the deep sediments and $N$. aff. spumigena to the littoral zone [75-78]. Then, $C$. alchichicana constitutes the primary driver for nutrient $(C, N, P)$ transport to the deep sediments of Lake Alchichica [79-81] and could be acting as a "eutrophication buffer", explaining the low fluctuation of Chl- $a$ concentrations throughout the 20 year period.

Regarding zooplankton, [67] found that temperature increases negatively affected calanoid copepods. Then, the observed decreasing trend in the density and biomass of L. garciai could be related to the temperature increase. However, the direct effect of temperature may not be the only thing affecting the zooplankton in Lake Alchichica. Competition is the most important biotic interaction in communities with low species diversity, while predation becomes more significant as a structuring factor with increasing diversity [82].

Such seems to be the case in Lake Alchichica, where the three zooplankton species are herbivorous and compete for the same food resource (small-size phytoplankton). Then, changes in food availability associated with environmental changes, such as the temperature increase, may become relevant. As aforementioned, there was an increasing trend in the abundance and biomass of the inedible large-size phytoplankton, while there was a downward trend in the edible, small-size (e.g., M. minutum) or medium-size (e.g., $O$. submarina) species. This could be a consequence of the higher consumption of small-size phytoplankton by zooplankton, which promotes the increase in nutrient availability for inedible phytoplankton species [71]. As [83] observed in Lake Balaton, when nutrient concentration limits phytoplankton biomass (expressed as Chl-a), the reduction in the small-size phytoplankton biomass showed a much lesser decrease than the larger size fraction biomass. The latter implies a decrease in available food for Lake Alchichica's zooplankton, particularly the rotifers and the larval stages of the copepods, taking into account that the large-size diatoms are inedible for the copepods, even for those in the adult stage [46].

Ortega-Magagoitia et al. ([78]) found that the copepod is a better competitor for food than the two rotifer species, and that Brachionus sp. "Mexico" is a better competitor than Hexarthra sp. These differences are reflected in the composition of the lake's zooplankton, 
where L. garciai is dominant and present throughout the annual cycle, while Brachionus sp. "Mexico" is absent during part of the year, while Hexarthra sp. is generally the most sporadic species $[84,85]$.

On the long-term record, the decreasing trend in the small-size phytoplankton biomass may be related to the decrease in the abundance and biomass of the copepods, which is evidenced in the lower numbers and biomass of adults (males and females). The abundance and biomass of rotifers, which also feed mainly on small phytoplankton, despite being highly variable, have shown a decreasing trend over 18 years [84]. This trend could also be an indirect consequence of the temperature increase. While favouring the large-size and disfavouring the small-size phytoplankton, the result is limited food availability for copepods and rotifers, leading to competition between the better-suited copepods against the less resourceful rotifers [78]. Ortega-Mayagoitia et al. ([86]) findings on L. garciai phenotypic plasticity support our hypothesis that both temperature and food availability are most likely responsible of the L. garciai decrease in abundance and biomass.

The little, indirect association of climatic data with the seasonal plankton succession may be related to the estimated effect of climate change at the latitude $\left(19^{\circ} 24^{\prime} \mathrm{N}\right)$ of Lake Alchichica, which corresponds to the edge of the Hadley cell. According to [87], in possible climate futures, the Hadley Circulation would expand poleward, while the temperature would sightly increase. Then, a slight increase in temperature would be expected in the Lake Alchichica region, as it was found in the long-term air temperature analysis as mentioned.

The authors of [88] noted the IPCC did not forecast a major increase in precipitation in tropical regions, which largely explains why the precipitation in Lake Alchichica displayed no statistical increasing or decreasing trend. In addition, the proximity $(20-25 \mathrm{~km})$ of the lake to the Sierra Madre Oriental causes a rain shadow effect. This high altitude (up to $3700 \mathrm{~m}$ ) mountain range creates an orographic shadow originating from a leeward desertic $\left(<500 \mathrm{~mm} \mathrm{y}^{-1}\right)$ and cold (annual mean average $\left.14.4^{\circ} \mathrm{C}\right)$ region, the Llanos de San Juan, where Lake Alchichica resides.

\section{Conclusions}

The meteorological variables showed interannual variability. In the longer-termlonger than the period considered in the present study - air and water temperatures showed increasing trends in the range considered by the IPCC as indicative of climate change. Lake Alchichica maintained environmental and biological regularity associated with its warm monomictic thermal pattern. Phytoplankton was numerically dominated by small-size chlorophytes (e.g., Monoraphidium minutum) and in biomass by large-size diatoms (i.e., Cyclotella alchichicana). Zooplankton was dominated numerically and in biomass by the calanoid copepod Leptodiaptomus garciai. Nonetheless, we found an increasing trend of the large-size phytoplankton (C. alchichicana) and a decreasing trend of the small-size phytoplankton (e.g., O. submarina) and the L. garciai copepod. The Chl-a concentration showed no evidence of increasing trophic status. The increase in temperature could have (a) favoured the large-size over the small-size phytoplankton, (b) directly and negatively affected the development of L. garciai, and (c) indirectly affected L. garciai by a decrease in the small-size phytoplankton, the copepods' food resource.

Author Contributions: Conceptualization, J.A. and L.A.O.; data curation, J.A., R.F., G.V., L.A.O. and R.A.S.-A.; formal analysis, J.A., A.L., L.A.O., R.A.S.-A. and Ó.E.; funding acquisition, J.A.; investigation, J.A., A.L., R.F. and L.A.O.; methodology, J.A., A.L., R.F., M.G.O., L.A.O. and R.A.S.-A.; project administration, L.A.O.; resources, J.A.; software, A.L., L.A.O. and R.A.S.-A.; supervision, J.A. and L.A.O.; validation, J.A. and L.A.O.; visualization, J.A. and L.A.O.; writing-original draft, J.A., A.L., R.F., G.V., M.G.O., L.A.O., R.A.S.-A. and Ó.E.; writing-review and editing, J.A., A.L., R.F., G.V., M.G.O., L.A.O., R.A.S.-A. and Ó.E. All authors have read and agreed to the published version of the manuscript. 
Funding: This research was funded by CONACYT through the projects 0956-N9111, 25430-T, 34893-T, 41667, 49923, 103332, and 224893, the Universidad Nacional Autónoma de México DGAPA/PAPIIT through the projects IN204597, IN210806, IN221009, IN215512, IN219220, and IN231820, and by Programa de Investigación en Cambio Climático (PINCC 2012-2014, 2020-2021).

Institutional Review Board Statement: Not applicable.

Informed Consent Statement: Not applicable.

Data Availability Statement: Data are available from the authors upon reasonable request.

Acknowledgments: RASA thanks CONACYT for the doctoral scholarship (CVU: 828517/scholarship 82851).

Conflicts of Interest: The authors certify that they have no affiliations with or involvement in any organization or entity with any financial interest (such as honoraria; educational grants; participation in speakers' bureaus; membership, employment, consultancies, stock ownership, or other equity interest; expert testimony or patent-licensing arrangements) or non-financial interest (such as personal or professional relationships, affiliations, knowledge or beliefs) in the subject matter or materials discussed in this manuscript.

\section{References}

1. Lewis, S.L.; Maslin, M.A. Defining the Anthropocene. Nature 2015, 519, 171-180. [CrossRef] [PubMed]

2. Smol, J.P. Under the radar: Long-term perspectives on ecological changes in lakes. Proc. R. Soc. B Biol. Sci. 2019, $286,20190834$. [CrossRef] [PubMed]

3. Heino, J.; Alahuhta, J.; Bini, L.M.; Cai, Y.; Heiskanen, A.; Hellsten, S.; Kortelainen, P.; Kotamäki, N.; Tolonen, K.T.; Vihervaara, P.; et al. Lakes in the era of global change: Moving beyond single-lake thinking in maintaining biodiversity and ecosystem services. Biol. Rev. 2021, 96, 89-106. [CrossRef] [PubMed]

4. Luoto, T.P.; Nevalainen, L. Solar and atmospheric forcing on mountain lakes. Sci. Total Environ. 2016, 566-567, 168-174. [CrossRef]

5. Williamson, C.E.; Dodds, W.; Kratz, T.K.; Palmer, M.A. Lakes and streams as sentinels of environmental change in terrestrial and atmospheric processes. Front. Ecol. Environ. 2008, 6, 247-254. [CrossRef]

6. Williamson, C.E.; Saros, J.E.; Vincent, W.F.; Smol, J.P. Lakes and reservoirs as sentinels, integrators, and regulators of climate change. Limnol. Oceanogr. 2009, 54, 2273-2282. [CrossRef]

7. Adrian, R.; O’Reilly, C.M.; Zagarese, H.; Baines, S.B.; Hessen, D.O.; Keller, W.; Livingstone, D.M.; Sommaruga, R.; Straile, D.; Van Donk, E.; et al. Lakes as sentinels of climate change. Limnol. Oceanogr. 2009, 54, 2283-2297. [CrossRef]

8. Tranvik, L.J.; Downing, J.A.; Cotner, J.B.; Loiselle, S.A.; Striegl, R.G.; Ballatore, T.J.; Dillon, P.; Finlay, K.; Fortino, K.; Knoll, L.B.; et al. Lakes and reservoirs as regulators of carbon cycling and climate. Limnol. Oceanogr. 2009, 54, 2298-2314. [CrossRef]

9. Woolway, R.I.; Kraemer, B.M.; Lenters, J.D.; Merchant, C.J.; O’Reilly, C.M.; Sharma, S. Global lake responses to climate change. Nat. Rev. Earth Environ. 2020, 1, 388-403. [CrossRef]

10. Gomes, A.M.D.A.; Marinho, M.M.; Berjante Mesquita, M.C.; Prestes, A.C.C.; Lürling, M.; Azevedo, S.M.F.O. Warming and eutrophication effects on the phytoplankton communities of two tropical water systems of different trophic states: An experimental approach. Lakes Reserv. Sci. Policy Manag. Sustain. Use 2020, 25, 275-282. [CrossRef]

11. Saulnier-Talbot, É.; Gregory-Eaves, I.; Simpson, K.G.; Efitre, J.; Nowlan, T.E.; Taranu, Z.E.; Chapman, L.J. Small Changes in Climate Can Profoundly Alter the Dynamics and Ecosystem Services of Tropical Crater Lakes. PLoS ONE 2014, 9 , e86561. [CrossRef] [PubMed]

12. Burnett, A.P.; Soreghan, M.J.; Scholz, C.A.; Brown, E.T. Tropical East African climate change and its relation to global climate: A record from Lake Tanganyika, Tropical East Africa, over the past 90+ kyr. Palaeogeogr. Palaeoclimatol. Palaeoecol. 2011, 303, 155-167. [CrossRef]

13. Scholz, C.A.; King, J.W.; Ellis, G.S.; Swart, P.K.; Stager, J.C.; Colman, S.M. Paleolimnology of Lake Tanganyika, East Africa, over the past 100 kyr. J. Paleolimnol. 2003, 30, 139-150. [CrossRef]

14. Livingstone, D.A. Global Climate Change Strikes a Tropical Lake. Science 2003, 301, 468-469. [CrossRef] [PubMed]

15. Plisnier, P.-D.; Nshombo, M.; Mgana, H.; Ntakimazi, G. Monitoring climate change and anthropogenic pressure at Lake Tanganyika. J. Great Lakes Res. 2018, 44, 1194-1208. [CrossRef]

16. Caballero, M.; Vázquez, G.; Lozano-García, S.; Rodríguez, A.; Sosa-Nájera, S.; Ruiz-Fernández, A.C.; Ortega, B. Present Limnological Conditions and Recent (ca. 340 yr) Palaeolimnology of a Tropical Lake in the Sierra de Los Tuxtlas, Eastern Mexico. J. Paleolimnol. 2006, 35, 83-97. [CrossRef]

17. Caballero, M.; Mora, L.; Muñoz, E.; Escolero, O.; Bonifaz, R.; Ruiz, C.; Prado, B. Anthropogenic influence on the sediment chemistry and diatom assemblages of Balamtetik Lake, Chiapas, Mexico. Environ. Sci. Pollut. Res. 2020, 27, 15935-15943. [CrossRef] 
18. Lozano-García, S.; Figueroa-Rangel, B.; Sosa-Nájera, S.; Caballero, M.; Noren, A.J.; Metcalfe, S.E.; Tellez-Valdés, O.; OrtegaGuerrero, B. Climatic and anthropogenic influences on vegetation changes during the last 5000 years in a seasonal dry tropical forest at the northern limits of the Neotropics. Holocene 2021, 31, 802-813. [CrossRef]

19. Rodríguez-Ramírez, A.; Caballero, M.; Roy, P.; Ortega, B.; Vázquez-Castro, G.; Lozano-García, S. Climatic variability and human impact during the last 2000 years in western Mesoamerica: Evidence of late Classic (AD 600-900) and Little Ice Age drought events. Clim. Past 2015, 11, 1239-1248. [CrossRef]

20. Alcocer, J.; Delgado, C.N.; Sommaruga, R. Photoprotective compounds in zooplankton of two adjacent tropical high mountain lakes with contrasting underwater light climate and fish occurrence. J. Plankton Res. 2020, 42, 105-118. [CrossRef]

21. García, E. Modoficaciones al Sistema de Clasificación Climática de Köppen (Para Adaptarlo a las Condiciones de la República Mexicana); Cuarta edi; Offset Larios: Ciudad de México, México, 1988.

22. Adame, M.F.; Alcocer, J.; Escobar, E. Size-fractionated phytoplankton biomass and its implications for the dynamics of an oligotrophic tropical lake. Freshw. Biol. 2008, 53, 22-31. [CrossRef]

23. Silva-Aguilera, R.; Escolero, O.; Alcocer, J. Recent Climate of Serdán-Oriental Basin. In Lake Alchichica Limnology. The Uniqueness of a Tropical Maar Lake; Javier, A., Ed.; Springer: Cham, Switzerland, 2022; pp. 51-91. ISBN 978-3-030-79095-0.

24. Filonov, A.; Tereshchenko, I.; Barba-López, M.R.; Alcocer, J.; Ladah, L. Meteorological regime, local climate, and hydrodynamics of Lake Alchichica. In Lake Alchichica Limnology: The Uniqueness of a Tropical Maar Lake; Alcocer, J., Ed.; Springer: Cham, Switzerland, 2022; ISBN 978-3-030-79095-0.

25. Armienta, M.A.; Vilaclara, G.; De la Cruz-Reyna, S.; Ramos, S.; Ceniceros, N.; Cruz, O.; Aguayo, A.; Arcega-Cabrera, F. Water chemistry of lakes related to active and inactive Mexican volcanoes. J. Volcanol. Geotherm. Res. 2008, 178, 249-258. [CrossRef]

26. Alcocer, J.; Lugo, A.; Escobar, E.; Sànchez, M.R.; Vilaclara, G. Water column stratification and its implications in the tropical warm monomictic Lake Alchichica, Puebla, Mexico. Verhandlungen Int. Verein Limnol. 2000, 27, 3166-3169. [CrossRef]

27. Ramírez-Olvera, M.A.; Alcocer, J.; Merino-Ibarra, M.; Lugo, A. Nutrient limitation in a tropical saline lake: A microcosm experiment. Hydrobiologia 2009, 626, 5-13. [CrossRef]

28. Searcy, J.K.; Hardison, C.H. Double-Mass Curves (No. 1541). Manual of Hydrology: Part 1. General Surface-Water Techniques. Water-Supply Paper; USGPO: Washington, DC, USA, 1960.

29. Arar, E.J.; Collins, G.B. Method 445.0 In Vitro Determination of Chlorophyll and Pheophytin a in Marine and Freshwater Algae by Fluorescence; U.S. Environmental Protection Agency: Cincinnati, OH, USA, 1997.

30. Utermöhl, H. Zur Vervollkomung der quantitativen Phytoplankton-Methodik. Mitt. Int. Ver. Limnol. 1958, 9, 1-38.

31. Olenina, I.; Hajdu, S.; Edler, L.; Andersson, A.; Wasmund, N.; Busch, S.; Göbel, J.; Gromisz, S.; Huseby, S.; Huttunen, M.; et al. Biovolumes and Size-Classes of Phytoplankton in the Baltic Sea; No. 106.; HELCOM: Helsinki, Finland, 2006; ISBN $0357-2994$.

32. Comas-González, A. Las Chlorococcales Dulceacuícolas de Cuba [The Freshwater Chlorococcids of Cuba]; Bibliotheca Phycologica: Stuttgart, Berlin, 1996.

33. Krammer, K. Large-Bertalot Suesswasserflora von Mitteleuropa. Band 2/3: Bacillariophyceae, 3. Teil: Bacillariaceae (Centrales, Fragilariaceae, Eunotionaceae); Springer Spektrum: Stuttgart, Germany, 1991.

34. Komárek, J.; Fott, B. Chlorophyceae (Gruenalgen), Ordnung Chlorococcales. (Huber-Pestalozzi, G. Das Phytoplankton des Siuesswassers. 7. Teil, 1. Haelfte). In Die Binnengewaesser; Huber-Pestalozzi, Ed.; Schweizerbart’sche Buchhandlung: Stuttgart, Germany, 1983.

35. Lehtimäki, J.; Lyra, C.; Suomalainen, S.; Sundman, P.; Rouhiainen, L.; Paulin, L.; Salkinoja-Salonen, M.; Sivonen, K. Characterization of Nodularia strains, cyanobacteria from brackish waters, by genotypic and phenotypic methods. Int. J. Syst. Evol. Microbiol. 2000, 50, 1043-1053. [CrossRef] [PubMed]

36. Oliva, M.G.; Lugo, A.; Alcocer, J.; Cantoral-Uriza, E.A. Cyclotella alchichicana sp. nov. from a saline mexican lake. Diatom Res. 2006, 21, 81-89. [CrossRef]

37. Oliva, M.G.; Lugo, A.; Alcocer, J.; Cantoral-Uriza, E.A. Morphological study of Cyclotella choctawhatcheeana prasad (Stephanodiscaceae) from a saline Mexican lake. Saline Syst. 2008, 4, 1-9. [CrossRef]

38. Rushfnrth, S.R.; Johansen, J.R. The inland Chaetoceros (Bacillariophyceae) species of North America. J. Phycol. 1986, 22, 441-448. [CrossRef]

39. Tavera, R.; Komárek, J. Cyanoprokariotes in the volcanic lake of Alchichica, Puebla State, Mexico. Die Binnengewaesser 1983, 83, 511.

40. Wehr, J.D.; Sheath, R.G.; Kociolek, J.P. Freshwater Algae of North America, 2nd ed.; Academic Press: Cambridge, MA, USA, 2015.

41. Dusart, B.H.; Defayane, D. Introduction to the Copepoda; SPB: Amsterdam, The Netherlands, 1995.

42. Cassie, R.M. Sampling and Statistics. In A Manual on Methods for the Assessment of Secondary Productivity in Freshwaters.; Edmonson, W.T., Winberg, G.G., Eds.; Blackwell: Oxford and Edinburgh, UK, 1971; pp. 174-209.

43. Koste, W. Rotatoria: D. Rädertiere Mitteleuropas e. Bestimmungswerk; Überordnung Monogononta, 1st ed.; Gebrüder Borntraeger Verlag: Berlin, Germany, 1978.

44. Mills, S.; Alcántara-Rodríguez, J.A.; Ciros-Pérez, J.; Gómez, A.; Hagiwara, A.; Galindo, K.H.; Jersabek, C.D.; Malekzadeh-Viayeh, R.; Leasi, F.; Lee, J.S.; et al. Fifteen species in one: Deciphering the Brachionus plicatilis species complex (Rotifera, Monogononta) through DNA taxonomy. Hydrobiologia 2017, 796, 39-58. [CrossRef] 
45. Montiel-Martínez, A.; Ciros-Pérez, J.; Ortega-Mayagoitia, E.; Elías-Gutiérrez, M. Morphological, ecological, reproductive and molecular evidence for Leptodiaptomus garciai (Osorio-Tafall 1942) as a valid endemic species. J. Plankton Res. 2008, 30, 1079-1093. [CrossRef]

46. Ciros-Pérez, J.; Ortega-Mayagoitia, E.; Alcocer, J. The role of ecophysiological and behavioral traits in structuring the zooplankton assemblage in a deep, oligotrophic, tropical lake. Limnol. Oceanogr. 2015, 60, 2158-2172. [CrossRef]

47. Ruttner-Kolisko, A. Suggestions for biomass calculation of plankton rotifers. Arch. Hydrobiol. Beih. Ergebn. Limnol. 1977, 8, 71-76.

48. McCauley, E. The estimation of the abundance and biomass of zooplankton in samples. In A Manual on Methods for the Assessment of Secondary Productivity in Fresh Waters; Downing, J., Rigler, F.H., Eds.; Blackwell Scientific Pub: Norkfold, England, 1984; pp. 228-265.

49. R Core Team. R: A Language and Environment for Statistical Computing; R Core Team: Vienna, Austria, 2021.

50. Laboratory, N.P.S. Climate Indices: Monthly Atmospheric and Ocean Time-Series. Available online: https://psl.noaa.gov/data/ climateindices/list/ (accessed on 28 February 2022).

51. Hammer, Ø.; Harper, D.A.T.; Ryan, D. PAST: Paleontological Statistics Software Package for Education and Data Analysis. Paleontol. Electron. 2001, 4, 9 .

52. Cuevas-Lara, J.D.; Alcocer, J.; Oseguera, L.A.; Quiroz-Martínez, B. Dinámica a largo plazo (1999-2014) de la productividad primaria fitoplanctónica en el Lago Alchichica. In Estado Actual del Conocimiento del Ciclo del Carbono y Sus Interacciones en México: Sintesis a 2016; Paz, F., Torres, R., Eds.; Programa Mexicano del Carbono en colaboración con la Universidad Autónoma del Estado de Hidalgo: Texcoco, Mexico, 2016; pp. 280-286. ISBN 978-607-96490-4-3.

53. Lewis, W.M. A revised classification of lakes based on mixing. Can. J. Fish. Aquat. Sci. 1983, 40, 1779-1787. [CrossRef]

54. Alcocer, J. (Ed.) Lake Alchichica Limnology_The Uniqueness of a Tropical Maar Lake.; Springer: Cham, Switzerland, 2022; ISBN 978-3-030-79095-0.

55. Alcocer, J.; Lugo, A. Effects of El Niño on the dynamics of Lake Alchichica, central Mexico. Geofísica Int. 2003, 42, 523-528.

56. Bravo-Cabrera, J.L.; Azpra-Romero, E.; Zarraluqui-Such, V.; Gay-Garcia, C. Effects of El Niño in Mexico during rainy and dry seasons: An extended treatment. Atmósfera 2017, 30, 221-232. [CrossRef]

57. Park, J.; Byrne, R.; Böhnel, H. The combined influence of Pacific decadal oscillation and Atlantic multidecadal oscillation on central Mexico since the early 1600s. Earth Planet. Sci. Lett. 2017, 464, 1-9. [CrossRef]

58. Pavia, E.G.; Graef, F.; Reyes, J. PDO-ENSO Effects in the Climate of Mexico. J. Clim. 2006, 19, 6433-6438. [CrossRef]

59. Trenberth, K.E. Recent observed interdecadal climate changes in the Northern Hemisphere. Bull. Am. Meteorol. Soc. 1990, 71, 988-993. [CrossRef]

60. Graham, N.E. Decadal-scale climate variability in the 1970's and 1980's: Observations and model results. Clim. Dyn. 1994, 10, 135-159. [CrossRef]

61. Latif, M.; Barnett, T.P. Causes of decadal climate variability over the North Pacific and North America. Science 1994, $266,634-637$. [CrossRef] [PubMed]

62. Minobe, S. A 50-70 year climatic oscillation over the North Pacific and North America. Geophys. Res. Lett. 1997, 24,683-686. [CrossRef]

63. Zhang, Y.; Wallace, J.M.; Battisti, D.S. ENSO-like interdecadal variability: 1900-93. J. Clim. 1997, 10, 1004-1020. [CrossRef]

64. IPCC. Intergovernmental Panel on Climate Change. In The Physical Science Basis. Contribution of Working Group I to the Fifth Assessment Report of the Intergovernmental Panel on Climate Change; Cambridge University Press: Cambridge, UK; New York, NY, USA, 2013.

65. Vadadi-Fülöp, C.; Sipkay, C.; Mészáros, G.; Hufnagel, L. Climate change and freshwater zooplankton: What does it boil down to? Aquat. Ecol. 2012, 46, 501-519. [CrossRef]

66. Michelutti, N.; Wolfe, A.P.; Cooke, C.A.; Hobbs, W.O.; Vuille, M.; Smol, J.P. Climate change forces new ecological states in tropical Andean lakes. PLoS ONE 2015, 10, e0115338. [CrossRef]

67. Carter, J.L.; Schindler, D.E.; Francis, T.B. Effects of climate change on zooplankton community interactions in an Alaskan lake. Clim. Chang. Responses 2017, 4, 3. [CrossRef]

68. Lewis, W.M. Phytoplankton Succession in Lake Valencia, Venezuela. Hydrobiologia 1986, 138, 189-203. [CrossRef]

69. Richerson, P.J.; Neale, P.J.; Wurtsbaugh, W.; Alfaro, T.R.; Vincent, W. Patterns of temporal variation in Lake Titicaca. A high altitude tropical lake. I. Background, physical and chemical processes, and primary production. Hydrobiologia 1986, 138, 205-220. [CrossRef]

70. Paul, C.; Sommer, U.; Matthiessen, B. Composition and dominance of edible and inedible phytoplankton predict responses of Baltic Sea summer communities to elevated temperature and $\mathrm{CO}_{2}$. Microorganisms 2021, 9, 2294. [CrossRef] [PubMed]

71. Bell, T. The ecological consequences of unpalatable prey: Phytoplankton response to nutrient and predator additions. Oikos 2002, 99, 59-68. [CrossRef]

72. Catalan, J.; Pla-Rabés, S.; Wolfe, A.P.; Smol, J.P.; Rühland, K.M.; Anderson, N.J.; Kopáček, J.; Stuchlík, E.; Schmidt, R.; Koinig, K.A.; et al. Global change revealed by palaeolimnological records from remote lakes: A review. J. Paleolimnol. 2013, 49, 513-535. [CrossRef]

73. Silva-Aguilera, R.A.; Vilaclara, G.; Armienta, M.A.; Escolero, O. Hydrogeology and hydrochemistry of the Serdán-Oriental Basin and the Lake Alchichica. In Lake Alchichica Limnology_-The Uniqueness of a Tropical Maar Lake; Alcocer, J., Ed.; Springer: Cham, Switzerland, 2022; ISBN 978-3-030-79095-0. 
74. González Contreras, C.G.; Alcocer, J.; Oseguera, L.A. Phytoplankton chlorophyll a in the tropical deep Alchichica: A long-term record (1999-2010). Hidrobiológica 2015, 25, 347-356.

75. Ardiles, V.; Alcocer, J.; Vilaclara, G.; Oseguera, L.A.; Velasco, L. Diatom fluxes in a tropical, oligotrophic lake dominated by large-sized phytoplankton. Hydrobiologia 2012, 679, 77-90. [CrossRef]

76. Escobar, E.; Alcocer, J. Lake foof webs. In Lake Alchichica Limnology—The Uniqueness of a Tropical Maar Lake; Alcocer, J., Ed.; Springer: Cham, Switzerland, 2022; ISBN 978-3-030-79095-0.

77. Oliva, M.G.; Lugo, A.; Alcocer, J.; Peralata, L.; Oseguera, L.A. Planktonic bloom-forming Nodularia in the saline Lake Alchichica, Mexico. Nat. Resour. Environ. Issues 2009, 15, 121-126.

78. Ortega-Mayagoitia, E.; Ciros-Pérez, J.; Sánchez-Martínez, M. A story of famine in the pelagic realm: Temporal and spatial patterns of food limitation in rotifers from an oligotrophic tropical lake. J. Plankton Res. 2011, 33, 1574-1585. [CrossRef]

79. Vilaclara, G.; Oliva-Martinez, M.G.; Macek, M.; Ortega-Mayagoitia, E.; Alcantara-Hernandez, R.J.; Lopez-Vazquez, C. A unique community for an oligotrophic lake. In Lake Alchichica Limnology-The Uniqueness of a Tropical Maar Lake.; Alcocer, J., Ed.; Springer: Cham, Switzerland, 2022; ISBN 978-3-030-79095-0.

80. Alcocer, J.; Ruiz-Fernández, A.C.; Escobar, E.; Pérez-Bernal, L.H.; Oseguera, L.A.; Ardiles-Gloria, V. Deposition, burial and sequestration of carbon in an oligotrophic, tropical lake. J. Limnol. 2014, 73, 223-235. [CrossRef]

81. Oseguera, L.A.; Alcocer, J.; Vilaclara, G. Relative importance of dust inputs and aquatic biological production as sources of lake sediments in an oligotrophic lake in a semi-arid area. Earth Surf. Process. Landforms 2011, 36, 419-426. [CrossRef]

82. Kondoh, M. Foraging Adaptation and the relationship between food-web complexity and stability. Science 2003, $299,1388-1391$. [CrossRef]

83. Bernát, G.; Boross, N.; Somogyi, B.; Vörös, L.; G-Tóth, L.; Boros, G. Oligotrophication of Lake Balaton over a 20-year period and its implications for the relationship between phytoplankton and zooplankton biomass. Hydrobiologia 2020, 847, 3999-4013. [CrossRef]

84. Fernández, R.; Alcocer, J.; Lugo, A.; Oseguera, L.A.; Guadarrama-Hernández, S. Seasonal and interannual dynamics of pelagic rotifers in a tropical, saline, deep lake. Diversity 2022, 14, 113. [CrossRef]

85. Ortega-Mayagoitia, E.; Alcántara-Rodríguez, J.A.; Lugo-Vázquez, A.; Montiel-Martínez, A.; Ciros-Pérez, J. The joys and challenges of living in a saline, oligotrophic, warm monomictic lake. In Lake Alchichica Limnology: The Uniqueness of a Tropical Maar Lake; Alcocer, J., Ed.; Springer: Cham, Switzerland, 2022; ISBN 978-3-030-79095-0.

86. Ortega-Mayagoitia, E.; Hernández-Martínez, O.; Ciros-Pérez, J. Phenotypic plasticity of life-history traits of a calanoid copepod in a tropical lake: Is the magnitude of thermal plasticity related to thermal variability? PLoS ONE 2018, 13, e0196496. [CrossRef] [PubMed]

87. IPCC Summary for Policymakers. Climate Change 2021: The Physical Science Basis. Contribution of Working Group I to the Sixth Assessment Report of the Intergovernmental Panel on Climate Change; Masson-Delmotte, V., Zhai, P., Pirani, A., Connors, S.L., Péan, C., Berger, S., Caud, N., Chen, Y., Goldfarb, L., Gomis, M.I., et al., Eds.; Cambridge University Press: Cambridge, UK, 2021.

88. Sarmento, H.; Amado, A.M.; Descy, J.P. Climate change in tropical fresh waters (comment on the paper "Plankton dynamics under different climatic conditions in space and time" by de Senerpont Domis et al.). Freshw. Biol. 2013, 58, 2208-2210. [CrossRef] 